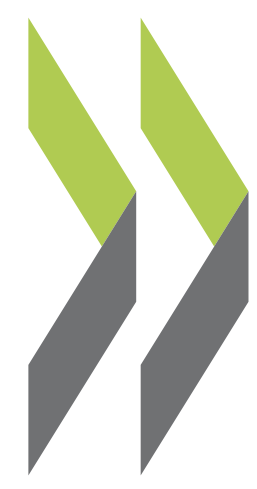

OECD Economics Department Working Papers No. 677

\title{
Quantifying the Effect of Financial Conditions in the Euro Area, Japan, United Kingdom and United \\ States
}

Stéphanie Guichard, David Haugh, David Turner 
Organisation de Coopération et de Développement Économiques

Organisation for Economic Co-operation and Development

\section{ECONOMICS DEPARTMENT}

QUANTIFYING THE EFFECT OF FINANCIAL CONDITIONS IN THE EURO AREA, JAPAN, UNITED KINGDOM AND UNITED STATES

ECONOMICS DEPARTMENT WORKING PAPERS No. 677

By Stéphanie Guichard, David Haugh and David Turner

All Economics Department Working Papers are available through OECD's internet web site at ww.oecd.org/working_papers 


\section{ABSTRACT/RÉSUMÉ \\ Quantifying the effect of financial conditions in the Euro Area, Japan, United Kingdom and United States}

This paper constructs a broad measure of financial conditions for the United States, Japan, the Euro Area and the United Kingdom, by extending monetary condition indices which are traditionally used to gauge the impact of monetary policy on the economy. In addition to changes in the exchange rate and short and long interest rates, the change in credit availability, corporate bond spreads and household wealth are taken into account to gauge the evolution of financial conditions. Since the onset of the financial crisis, financial conditions have tightened by an unprecedented degree in the four countries/regions and this is evaluated to exert a major drag on activity.

JEL Classification: E32; E44; E47; E51

Keywords: Financial conditions index; monetary conditions index; interest rate spreads; credit crunch; wealth effects; credit channel; macro-financial linkages

$$
* * * * *
$$

\section{Quantifier l'impact des conditions financières dans la Zone Euro, le Japon, le Royaume-Uni et les États-Unis}

Ce document propose une mesure des conditions financières au sens large pour les États-Unis, le Japon, la Zone Euro et le Royaume-Uni, en étendant les indices des conditions monétaires traditionnellement employés pour mesurer l'impact de la politique monétaire sur l'économie. En plus des variations du taux de change et des taux d'intérêt à court et long terme, l'évolution de la disponibilité du crédit, des primes de risques sur les obligations des sociétés et de la richesse des ménages sont prises en considération pour apprécier l'évolution des conditions financières. Depuis le début de la crise financière, le resserrement des conditions financières a attient un degré sans précédent dans les quatre pays/régions et ceci devrait peser fortement sur l'activité.

Classification JEL : E32 ; E44 ; E47 ; E51

Mots-clés : Indice des conditions financières ; indice des conditions monétaires ; écarts de taux d'intérêt ; contraction du crédit ; effet de richesse ; canal du crédit ; relations macro-financières

Copyright @ O OECD, 2009

Application for permission to reproduce or translate all, or part of, this material should be made to: Head of Publications Service, OECD, 2 rue André-Pascal, 75775 PARIS CEDEX 16, France. 


\section{TABLE OF CONTENTS}

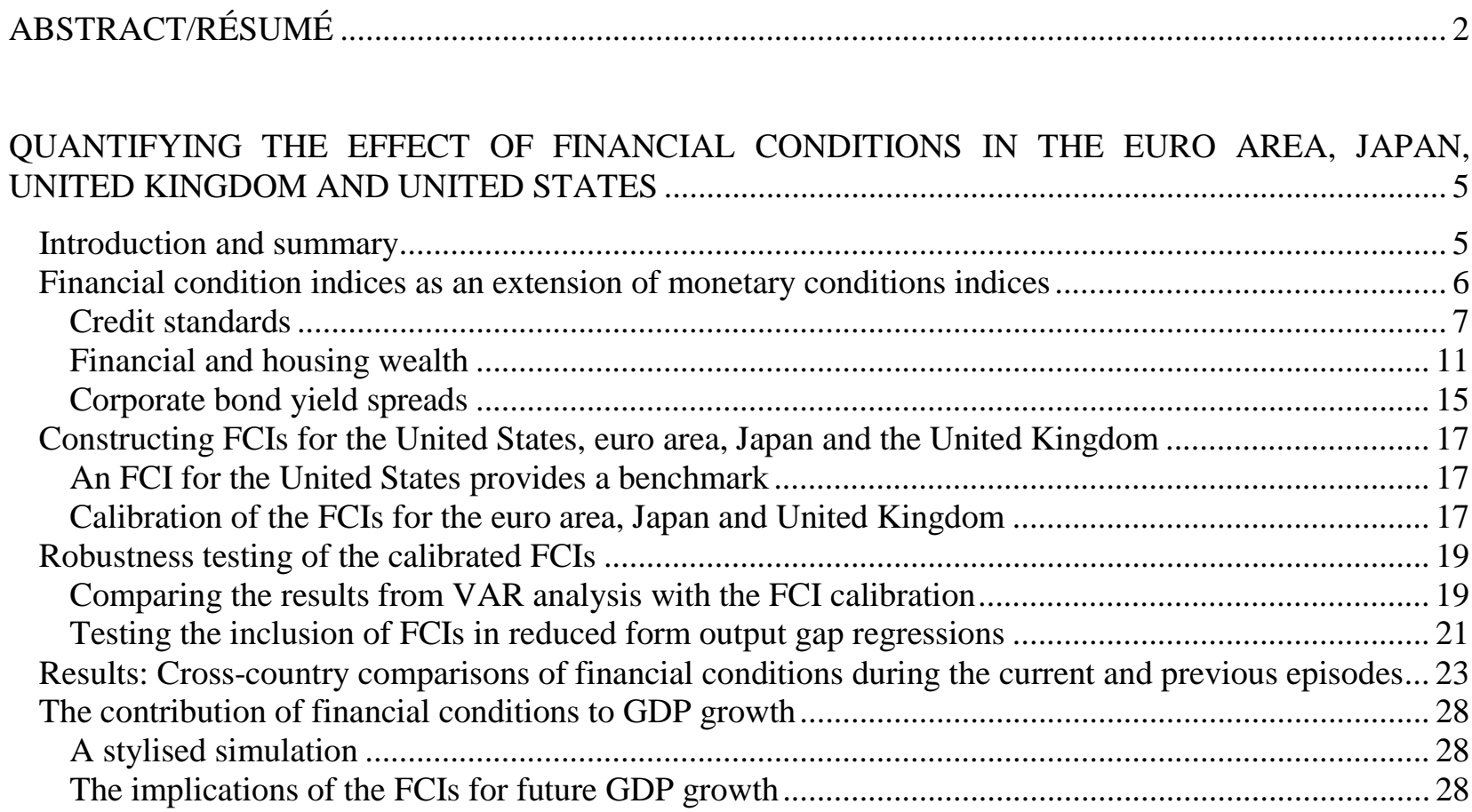

ANNEX 1: TESTING THE SIGNIFICANCE OF CREDIT STANDARDS IN ACCELERATOR-TYPE

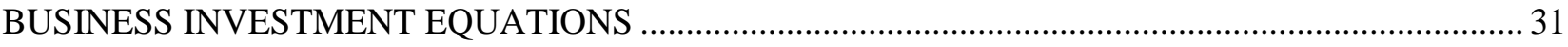

ANNEX 2: WHY HAS BANK LENDING CONTINUED TO GROW SO RAPIDLY? ........................... 32

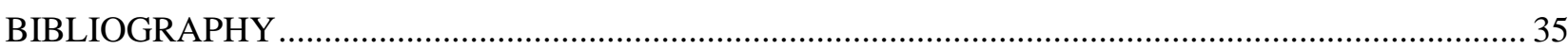

\section{Tables}

1. Net household financial wealth and estimates of equity holdings

2. Weights used in the construction of FCIs

3. Comparison of the weights used in the construction of FCIs with theVAR results

4. Testing the significance of the financial conditions indices in reduced form output gap equations

5. Accounting for the tightening in financial conditions since the onset of financial turmoil

A1.1 Testing credit conditions in accelerator equations for business investment

A2.1 Testing the significance of the credit conditions in business investment accelerator equations 


\section{Figures}

1. Banks are tightening lending standards

2. Growth in bank lending is slowing

3. Business surveys show a tightening of financial conditions in Japan

4. Business surveys show a tightening of financial conditions in the United Kingdom

5. Equity price indices have tumbled

6. Real house prices

7. Financial wealth effects

8a. Housing, financial and total wealth effects in the United States

8b. Housing, financial and total wealth effects in the United Kingdom

9. High yield spreads have reached record levels

10. Investment grade bond spreads have also surged

11a. The financial conditions index for the United States

11b. The financial conditions index for the euro area

11c. The financial conditions index for Japan

11d. The financial conditions index for the United Kingdom

12. Comparisons of financial conditions indices across countries

13. Simulation of a sustained fall in the FCI

14. Implications of the FCIs for GDP growth and the output gap

A2.1 Response of bank lending following a tightening in lending standards 
ECO/WKP(2009)18

\title{
QUANTIFYING THE EFFECT OF FINANCIAL CONDITIONS IN THE EURO AREA, JAPAN, UNITED KINGDOM AND UNITED STATES
}

\author{
By Stéphanie Guichard, David Haugh and David Turner ${ }^{1}$
}

\section{Introduction and summary}

1. The financial crisis has increased the cost and reduced the availability of external financing for enterprises and households. As banks have strived to improve their capital positions, they have tightened credit standards, especially in the United States and Europe. There have also been massive changes in asset prices; global equity indices have roughly halved from previous peaks and real house prices are now falling in most OECD countries; and spreads in debt markets have widened considerably. Central banks have responded by lowering policy rates, although the impact on market rates has been muted by the malfunctioning of money markets. Finally, particularly as the financial crisis intensified, there have been pronounced movements in exchange rates.

2. These developments affect activity, but in a way that is difficult to unravel quantitatively. This paper reviews the evolution of different aspects of financial conditions in the United States, the euro area, Japan and the United Kingdom, and assesses their influence on future growth. Quantifying the impact of financial variables on activity is inherently difficult: causation runs in both directions; financial variables are often highly correlated and there are problems of simultaneity, identification and double-counting; developments in financial markets may mean that the sensitivity of activity to financial conditions evolves over time; and linearity may be an inappropriate assumption, particularly given recent extreme movements in such variables. Despite these problems, a broad indicator which attempts to synthesise the effect of financial conditions on activity has already been built for the United States (Guichard and Turner, 2008) and used to summarise financial conditions in the OECD Economic Outlook (OECD, 2008b). This paper attempts to extend this approach to other countries, mainly through judgemental calibration using the existing US indicator as a reference point.

3. Given the inherent problems and the limited availability of data for some countries, considerable "health warnings" are appropriate in interpreting the new indicators. An ex post validation exercise does, however, provide some empirical support for the new indicators, which are found to be highly significant, both statistically and economically, in regressions explaining the output gap in all countries considered. Yet, direct interpretations of the levels of the indicators should be made with great caution. Using the indicators to make broad comparisons of financial conditions both across countries and episodes, the main findings of the paper are that:

- The weights of the different components of the FCI vary across countries/regions according to estimates of the relative sensitivity of activity to each component. For example, the weight of bank lending standards has a higher weight in Japan and the euro area, whereas corporate bond yields have a higher relative weight in the United States and the United Kingdom.

1. Thanks to Jorgen Elmeskov, Jean-Luc Schneider, Pete Richardson, Boris Cournède Masahiko Tsutsumi, Luke Willard for comments on previous drafts and also to Patrice Ollivaud and Elena Rusticelli for excellent statistical support and Anne Eggimann and Lise Perrault for help with document preparation. All remaining errors are our own responsibility. 
- The scale of the current financial shock in terms of its adverse implications for activity is unprecedented in recent history for the United States, euro area, Japan and the United Kingdom.

- A widening in corporate bond spreads, particularly since the third quarter of 2008, accounts for about 40 to $50 \%$ of the deterioration in financial conditions in all countries.

- The tightening in credit standards is also a major component of the worsening of financial conditions, accounting for one-third of it on average across all countries considered. The available measures of credit standards are, however, not fully comparable across countries.

- Lower equity prices, if maintained, are likely to be a major drag on activity over coming years in all major OECD countries, with wealth effects somewhat greater in the United States and United Kingdom given relatively larger equity holdings. These effects are likely to be reinforced by wealth or collateral effects from falling house prices, again especially in the United States and United Kingdom, so that the overall drag from wealth-type effects is expected to be greater than after the bursting of the high-tech bubble.

- The sharp appreciation of the yen in the second half of 2008 is estimated to account for one-third of the tightening in Japan's financial conditions while the depreciation of sterling represents a considerable partial offset, perhaps almost half, to the deterioration in financial conditions in the United Kingdom.

- As long as other aspects of financial conditions stay at their current levels, conventional monetary policy alone would not be able to bring financial conditions back to their long-term average. This underlines the need for less conventional forms of monetary easing, including quantitative easing and interventions to improve credit conditions over a range of financial markets and at different maturities.

4. The remainder of the paper is organised as follows: the first section presents the financial variables that are considered in the financial condition indices; the second section details the construction of these FCI; robustness checks are presented in the third section; the fourth section compares the evolution of these FCI over the recent and previous episodes of financial stress; a final section demonstrates how the FCIs can be used to infer the implications of financial conditions for future GDP growth

\section{Financial condition indices as an extension of monetary conditions indices}

5. Financial conditions indices (FCIs) are an extension of monetary condition indices which are sometimes computed to gauge the impact of monetary policy on the economy by weighting together changes in the exchange rate and short-term interest rates according to their relative effects on activity. FCI's are augmented with a broader set of variables, most usually equity prices and sometimes house prices, although there is no clear theoretical basis for which variables should be included and the choice is often empirically guided. ${ }^{2}$ Corporate bonds yields, or their spread with more risk-free government bond yields, are also included to better reflect a market measure of the cost of finance. An important recent extension is to include survey measures summarising the tightness of credit conditions, although so far this has only been applied to the United States (Guichard and Turner, 2008; Swiston, 2008). The remainder of this section focuses on the transmission channels of those variables which are included in the FCI in addition to the standard interest rate and exchange rate variables which are included in MCI's. It also highlights important data availability issues which arise in using these variables.

2. For example: Mayes and Virén (2001); Goodhart and Hofmann (2001); Gauthier, Graham, and Liu (2004). 


\section{Credit standards}

6. A number of studies have found significant links between survey-based measures of credit standards and GDP growth for the United States. Previous empirical work underlying the financial conditions index for the United States found that a net 10 percentage points tightening in the survey response on lending conditions is associated with a reduction in GDP by about $1 / 4$ per cent after four to six quarters (Guichard and Turner, 2008). The magnitude of this impact is smaller, but not dissimilar to those obtained by Lown and Morgan (2004) and Swiston (2008). There has been no comparable study for the euro area, the United Kingdom or Japan. However, these survey measures of lending standards do consistently have a statistically and economically significant impact in simple accelerator-type investment equations, while it is more difficult to find conventional interest rate effects (see Annex 1 and also Motonishi and Yoshikawa (1999) for evidence that such measures of credit standards have an effect on Japanese business investment).

7. Loan officer surveys in the United States, the euro area and the United Kingdom show that banks have tightened credit standards for all types of borrowers to a degree not previously experienced, although for the euro area and the United Kingdom the history over which most such survey responses are available is relatively short (Figure 1). The tightening in bank lending standards and the large estimated effects on activity may appear difficult to reconcile with the fact that bank lending to businesses continued to grow strongly throughout 2007 and has only recently begun to decelerate in the second half of 2008 (Figure 2). However, some delay between a tightening in lending standards and a slowdown in credit growth is not unusual, although this time the delay may have been accentuated by specific features related to the current crisis (Annex 2).

8. Data availability is a key problem regarding bank lending standards. While as previously noted, there is empirical evidence that such survey data bank on lending standards have a statistically and economically significant effect on real activity in the United States, equivalent data are not readily available over a long sample period for other countries.

- For the euro area, the ECB publishes the results of a bank lending survey, but responses are only available since 2003. To generate historical data the series was back-cast using the US credit standards variable, the slope of the yield curve and responses from a business survey relating to the ease of financing investment in France. ${ }^{3}$

- For Japan, responses to the loan officer survey on bank lending practices are only available from 2000. Instead, the results from the Tankan business survey on the perceived lending attitudes of banks are used, both because it is available over a longer sample and because empirical work suggested a closer link to GDP and investment (Figure 3). Although there is no significant contemporaneous correlation between the responses to the Tankan survey and the loan officer survey, a simple regression shows that a change in credit standards in the loan officer survey is reflected in a change in business sentiment regarding the lending attitudes of banks in subsequent quarters, consistent with a recognition lag.

3. The French investment survey is available since 1991 on a quarterly basis, but the question relating to financing conditions is only asked once a year. 
Figure 1. Banks are tightening lending standards

Net percentage of banks tightening credit

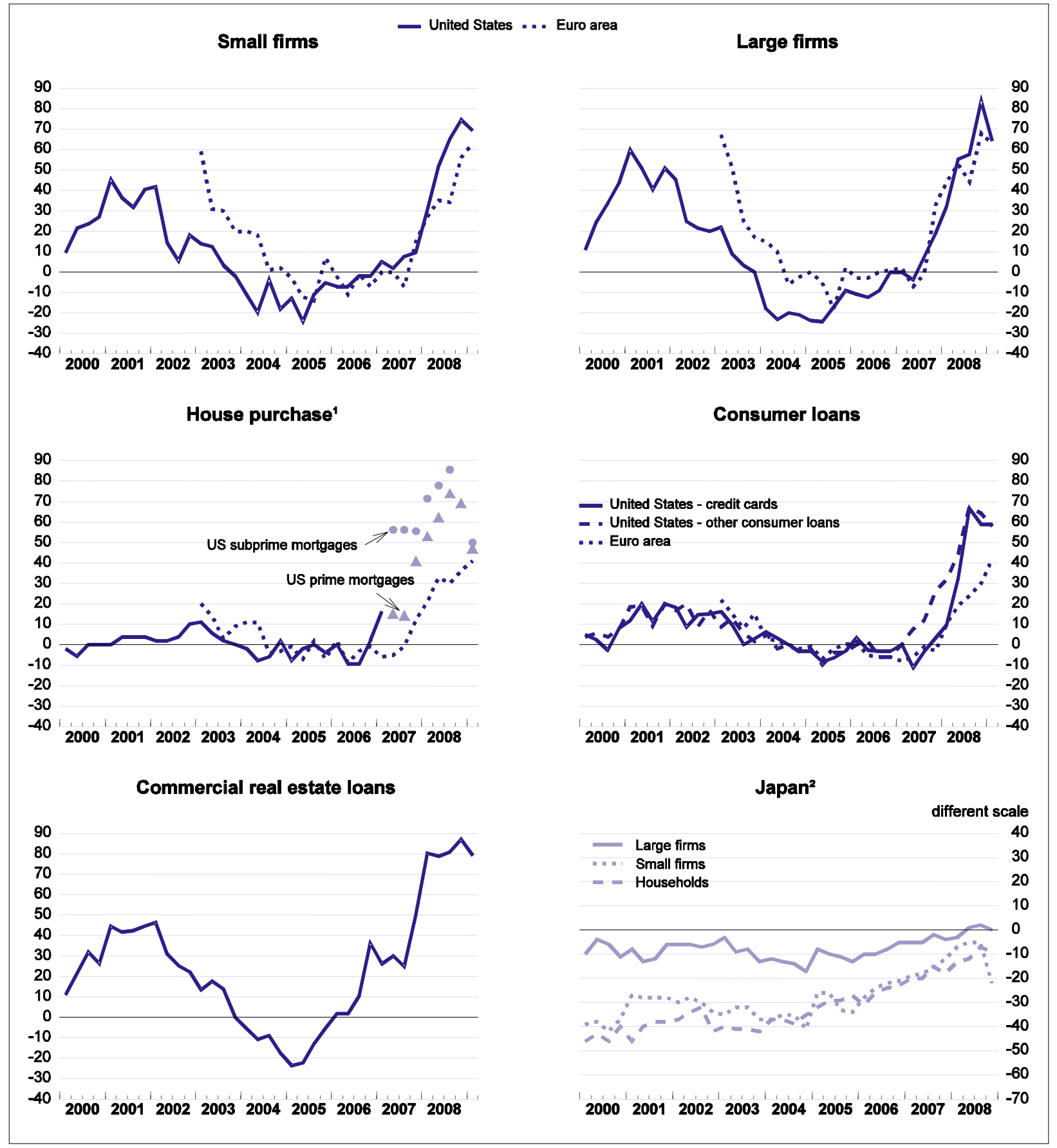

1. In the United States, starting in 2007q2 changes in standards for prime, non conventional (not displayed on this figure) and subprime mortgage loans are reported separately.

2. The Bank of Japan publishes a diffusion index of "accommodative" minus "severe". The data have then been transformed to show the net percentage of banks tightening credit, as for the United States and the euro area.

Source: US Federal Reserve, Senior Loan Officer Survey; ECB, The euro area bank lending survey; and Bank of Japan, Senior Loan Officer Opinion Survey. 
Figure 2. Growth in bank lending is slowing

Year-on-year growth rate

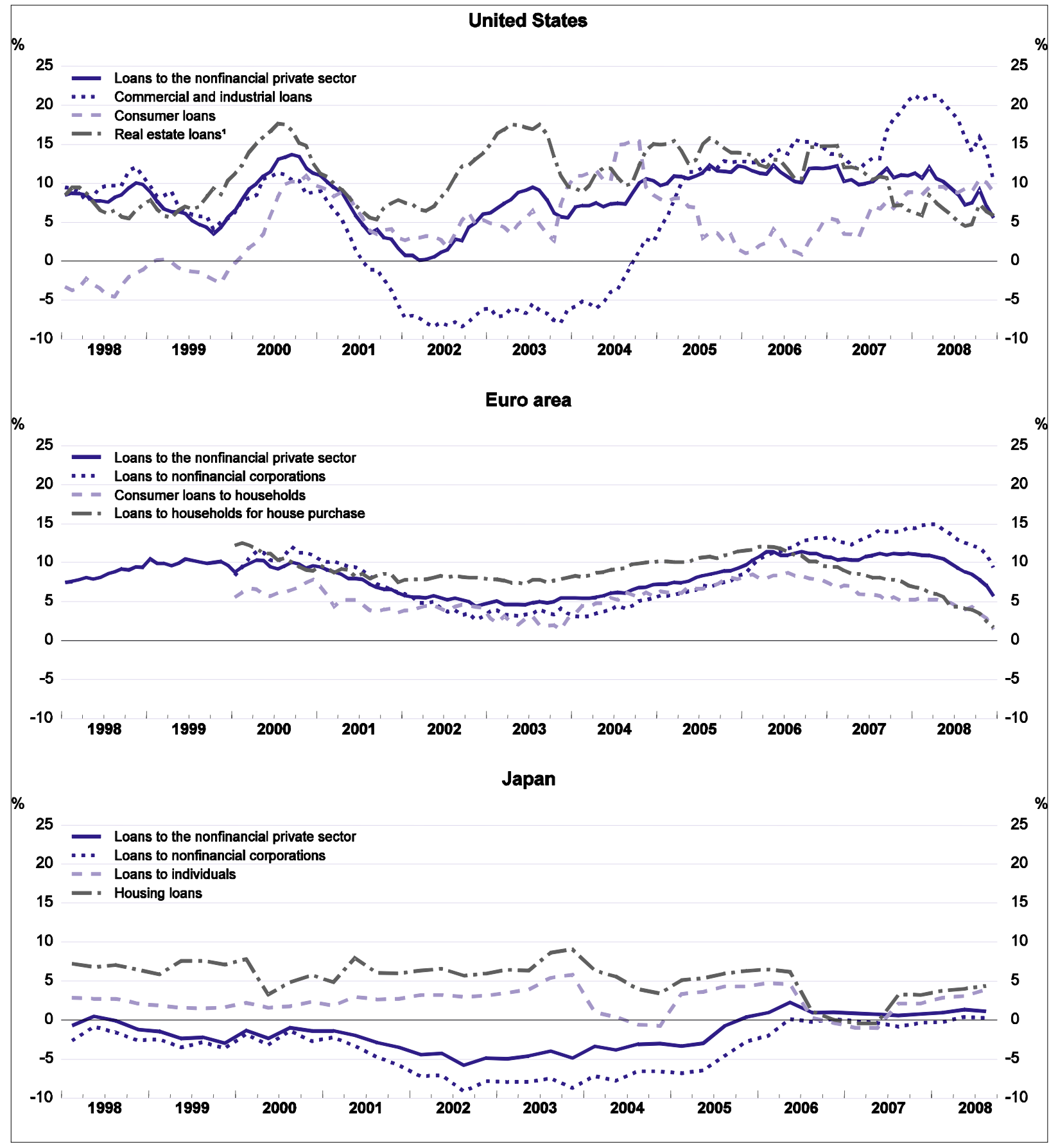

Note: Data refer to all commercial banks for the United States; to monetary financial institutions (MFIs) for the euro area. Year-onyear growth rates are calculated from end-of-period stocks. For the euro area, these are adjusted for reclassifications, exchange rates variations and any other changes which do not arise from transactions. For the United States, the end-of-sample increase in lending is driven by the reclassification of assets of Washington Mutual.

1. The definition of real estate loans for the United States is broader than housing loans as it includes also loans related to commercial real estate. Moreover, both for the United States and for Japan real estate / housing loans can include also loans to the corporate sector.

Source: Datastream. 
Figure 3. Business surveys show a tightening of financial conditions in Japan

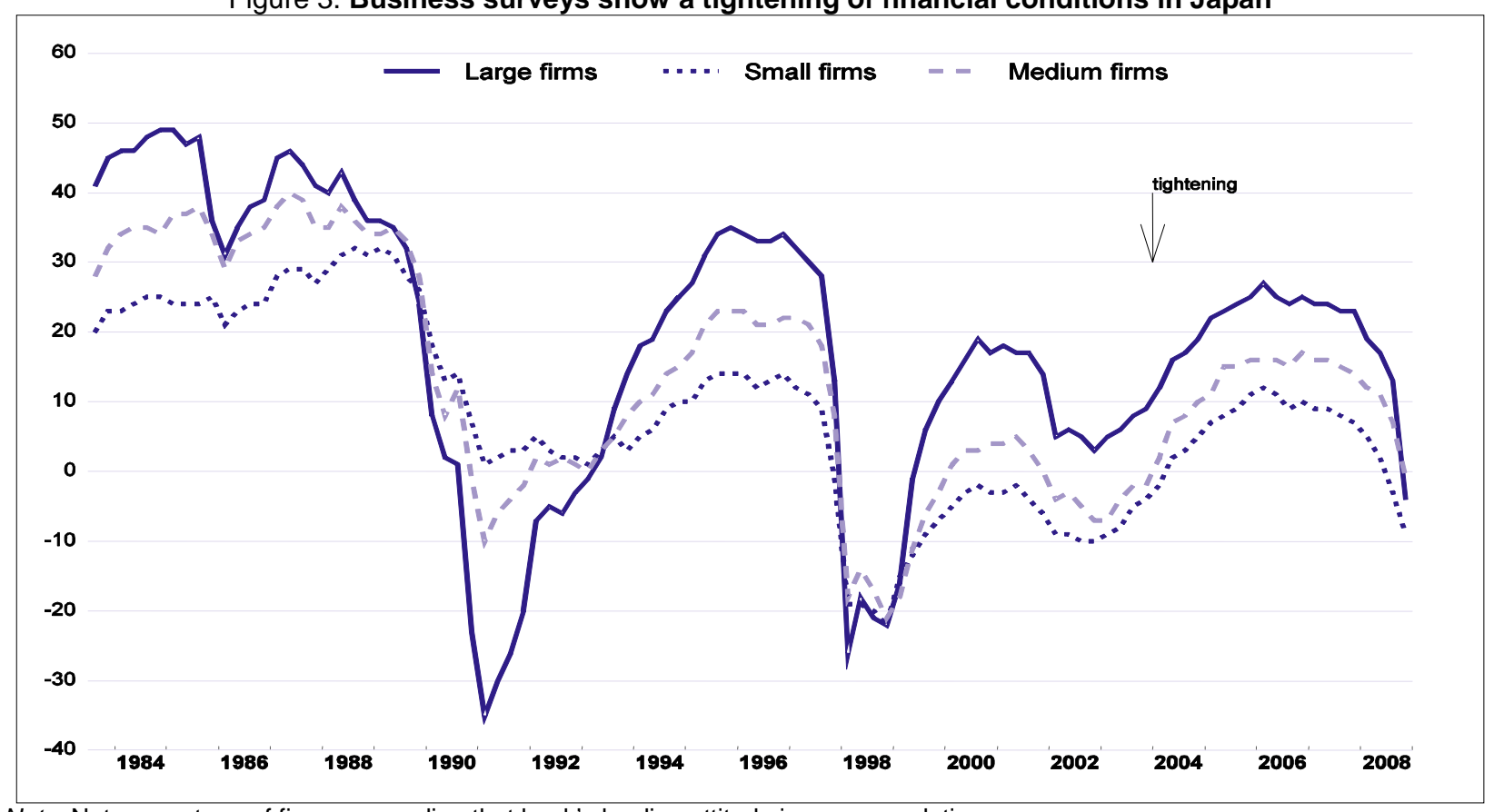

Note: Net percentage of firms responding that bank's lending attitude is accommodative.

Source: Bank of Japan TANKAN survey.

- For the United Kingdom, the Bank of England has only recently begun conducting a survey on credit conditions and so responses are only available since July 2007. Instead, responses to a question as to whether external finance is a factor limiting investment from the business survey conducted by the Confederation of British Industry (CBI) was used (Figure 4). Empirical work suggests that these responses have significant power in explaining business investment.

Figure 4. Business surveys show a tightening of financial conditions in the United Kingdom

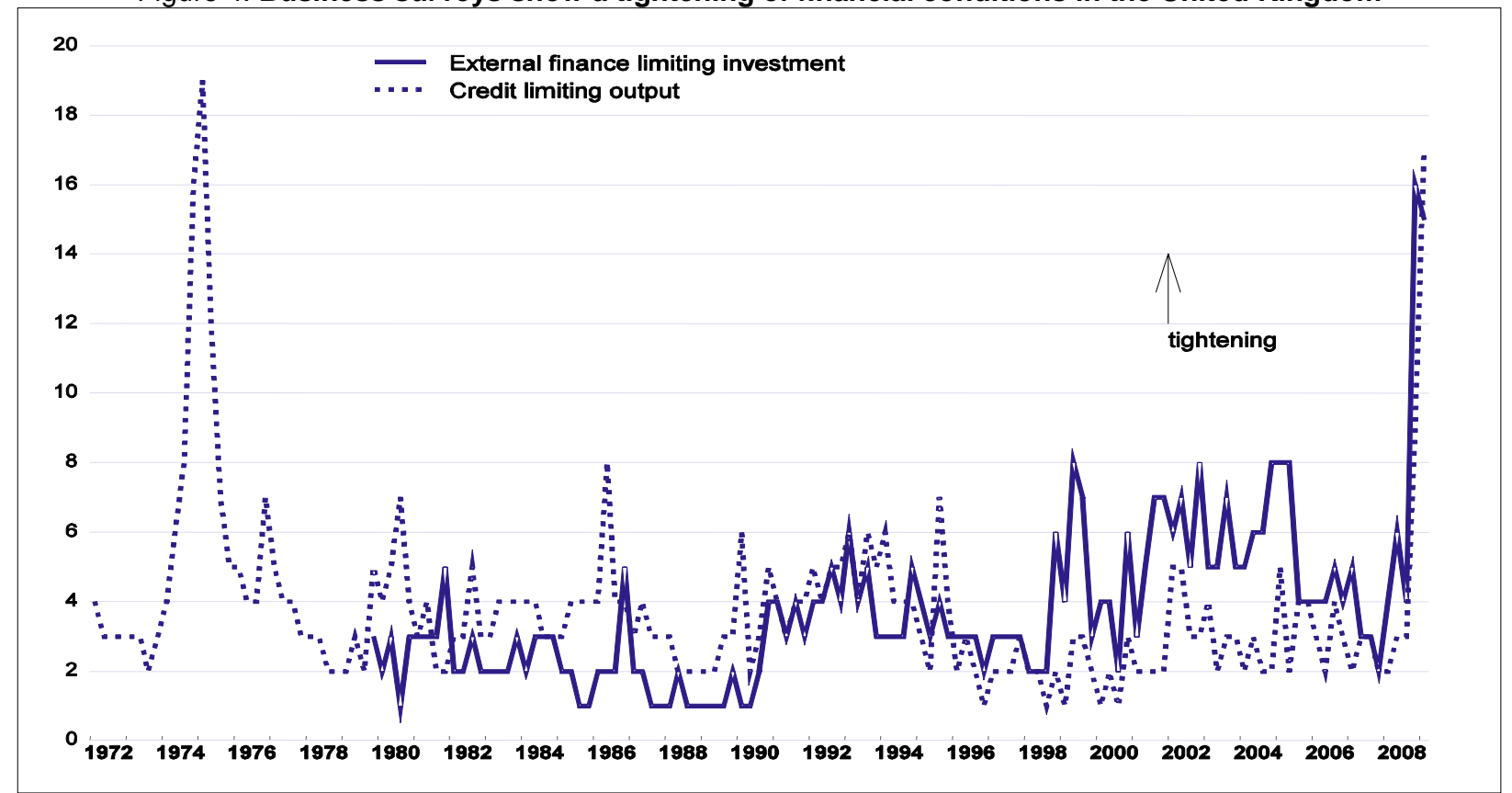

Note: Net percentage of firms answering that external finance is a factor limiting investment-external finance and that credit or finance is a factor limiting output. 


\section{Financial and housing wealth}

9. Falling asset prices can affect activity via various channels including through a wealth effect, via a financial accelerator or as a function of Tobin's Q. Wealth effects are easier to quantify and test for empirically than the latter two channels and so are the focus of the analysis presented here. Negative wealth effects will arise from the sharp declines in equity prices as well as past and ongoing falls in house prices. Equity price indices in the major OECD countries have roughly halved from recent peaks (Figure 5), with particularly steep falls being experienced as the financial crisis intensified in the second half of 2008 and real house prices are now falling in most OECD countries (Figure 6).

10. There is a wide range of estimates of the marginal propensity to consume out of financial wealth across different countries and studies, but recent research has cast some doubt as to whether such differences are statistically significant or whether large cross-country differences can plausibly be explained by differences in underlying demographic and structural factors (Altissimo et al., 2005; Labhard et al., 2005; Poterba, 2000).

Figure 5. Equity price indices have tumbled

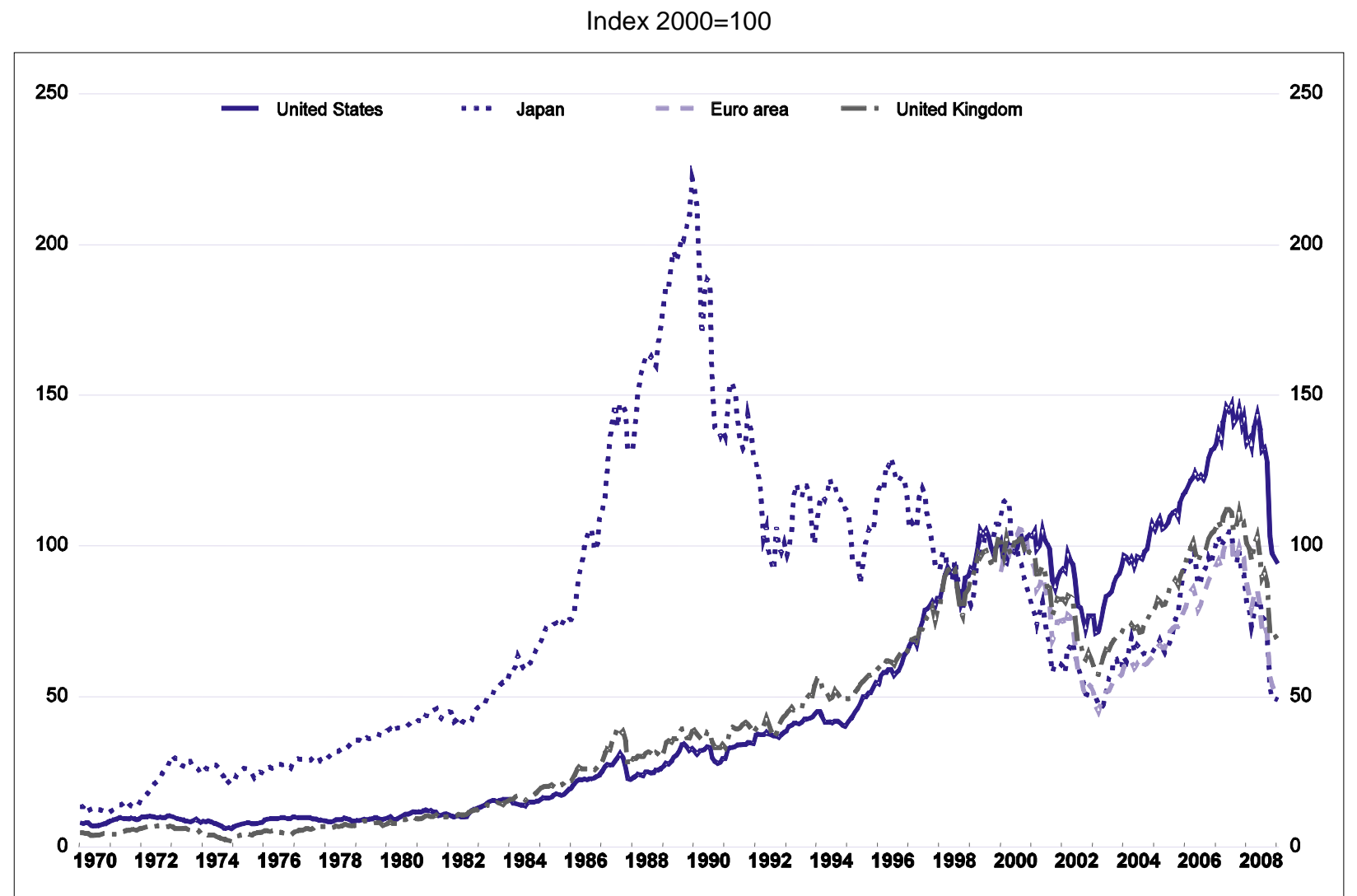

Note: Dow Jones Composite 65 for the United States; Nikkei 225 for Japan; Euronext 100 for the euro area; and FTSE for the United Kingdom.

Source: Datastream. 
Figure 6. Real house prices ${ }^{1}$

Index $2000=100$

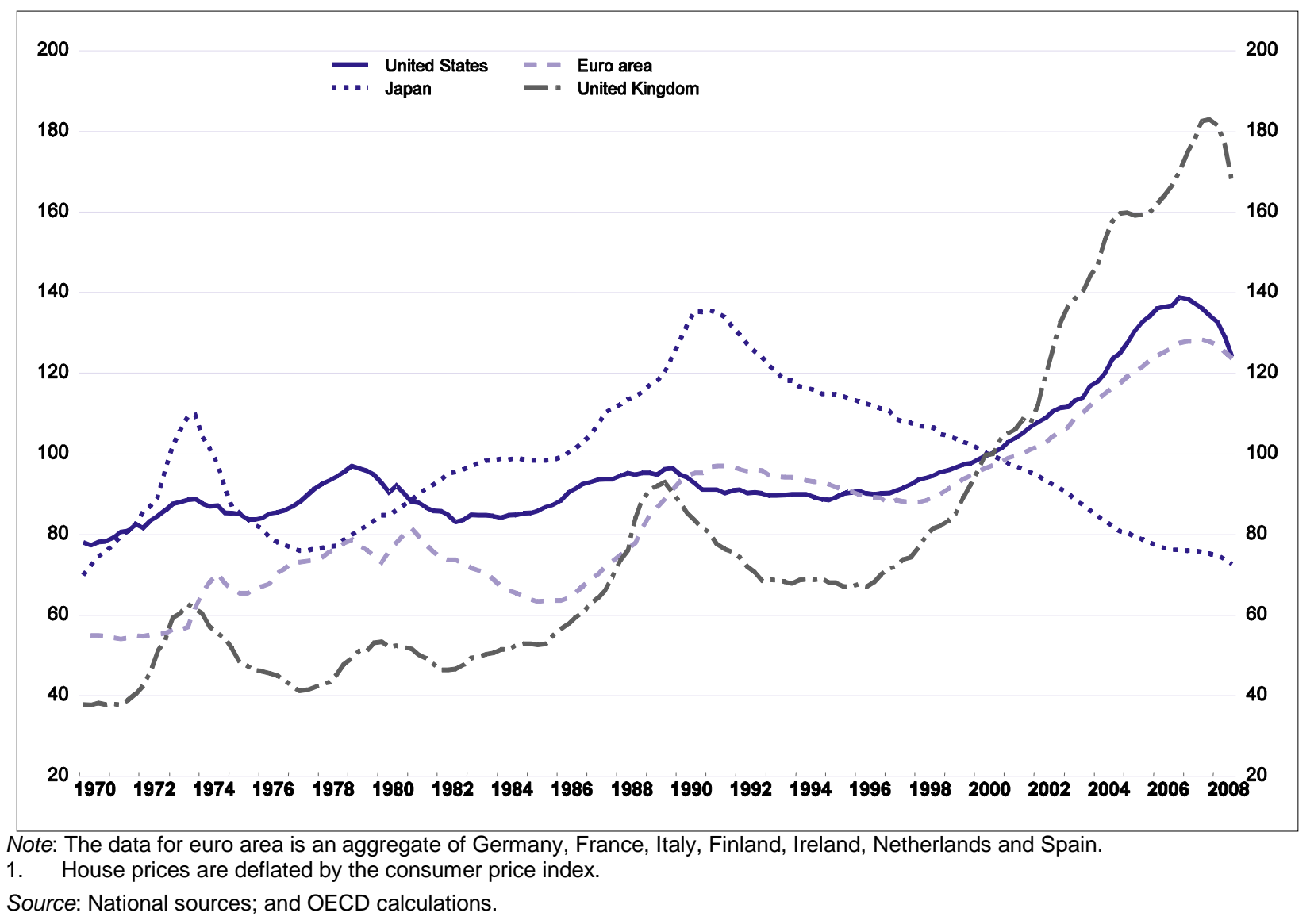

11. But even under the assumption of a common propensity to consume out of financial wealth, the effects of a similar percentage fall in equity prices will vary widely across countries because of the different holdings of equity wealth by households. Precise estimates of such holdings are not possible because they depend not only on direct household holdings of equity wealth, but also on indirect exposure via institutions such as pension funds. However, the share of equities in published estimates of financial wealth can be estimated by simple regressions which examine the sensitivity of financial wealth to equity prices (Table 1). These suggest that total (direct and indirect) equity holdings are a larger share (over half) of net financial wealth in the United States and United Kingdom than in either the euro area or Japan, as well as being larger in relation to personal disposable income. On this basis, and assuming a propensity to consume out of wealth of $0.04,{ }^{4}$ financial wealth effects from the sharp fall in equity prices imply a substantial drag on consumption over the next couple of years, subtracting as much as $1 \frac{1}{2}$ per cent from annualised consumption growth in the second half of 2009 and early in 2010 in the United States and United Kingdom, and up to $1 \%$ in the euro area and Japan (Figure 7). ${ }^{5}$

4. This estimate is close to the estimate used by the Federal Reserve Board for the United States (OECD, 2008a) as well as to an estimate for the euro area from recent empirical work by the Secretariat (OECD, 2009).

5. These calculations further assume that consumption adjusts gradually over the eight quarters following a shock to wealth. Financial wealth is projected by using observed equity prices to the end of 2008 and then 


\section{Table 1. Net household financial wealth and estimates of equity holdings}

as \% of disposable income

\begin{tabular}{lcccr} 
& $\begin{array}{c}\text { Net financial } \\
\text { wealth }\end{array}$ & $\begin{array}{c}\text { Direct equity } \\
\text { holdings }\end{array}$ & $\begin{array}{c}\text { Upper bound } \\
\text { on total } \\
\text { equity holdings }\end{array}$ & $\begin{array}{c}\text { Estimate of total } \\
\text { equity holdings } \\
\text { from regression }\end{array}$ \\
\cline { 2 - 5 } & 304 & 130 & 317 & 161 \\
United States & 214 & 65 & 189 & 81 \\
Euro area & 402 & 56 & 192 & 101 \\
Japan & 311 & 78 & 339 & 171 \\
United Kingdom & 362 & & \\
\hline
\end{tabular}

Notes: Estimates relate to 2007

1. The upper bound estimate is direct equity holdings plus assets that can have exposure to equities including mutual funds, insurance and pension fund assets.

2. The estimate of total equity holdings is derived from a regression of net financial wealth on own country and global equity price indices.

Sources: US Federal Reserve, Eurostat, Bank of Japan, UK Office of National Statistics, OECD.

Figure 7. Financial wealth effects

Effect on annualised consumption growth (\% pa)

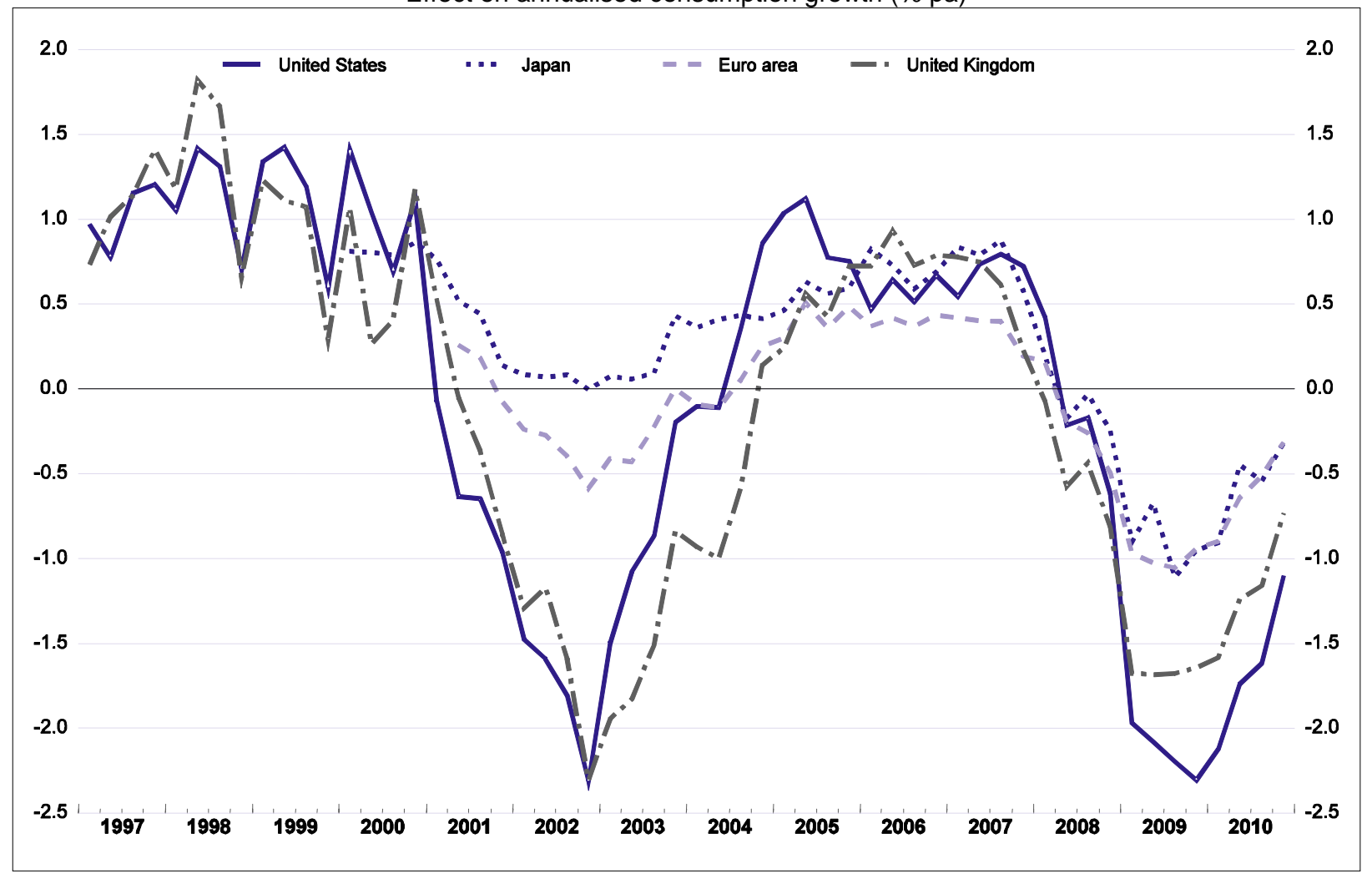

Note: Financial wealth is projected by using observed equity prices to the end of 2008 and then assuming financial wealth stays a constant proportion of GDP as projected in OECD Economic Outlook 84 database. The wealth effects are evaluated by assuming a marginal propensity to consume out of wealth of 0.04 realised over 8 quarters.

Source: US Federal Reserve Bank; Bank of Japan; Eurostat; Office of National Statistics of the United Kingdom; and OECD Economic Outlook 84 database.

assuming financial wealth stays a constant proportion of GDP as projected in the OECD Economic Outlook 84 database. 
12. OECD cross-country estimates suggest that effects from housing 'wealth' are typically larger and more statistically significant in countries with more liberal mortgage markets (Catte et al., 2003). ${ }^{6}$ This is consistent with house prices affecting consumption mainly via collateral effects, so that a rise in house prices principally affects the real economy by allowing liquidity constrained households to expand consumption by using housing as collateral to obtain loans on relatively favourable terms where mortgage markets are liberalised. On this basis effects from changes in housing wealth are estimated for the United States and the United Kingdom, but not for Japan or the euro area, assuming that the marginal propensity to consume out of housing wealth is again 0.04 (Figures 8a and b). No effect from housing wealth is included in the FCIs for Japan and the euro area because opportunities to use housing wealth as collateral for household borrowing are limited and because there is little empirical evidence of a positive link between housing wealth and consumption. Indeed, Muellbauer (2008) provides evidence that for Japan (as well as Italy), where the mortgage markets are relatively illiberal, higher house prices have a negative effect on consumption as younger adults are forced to save more to be able to afford a house. In addition, recent OECD empirical work finds no strong evidence of an effect from housing wealth (proxied by a measure of real house prices) on euro area consumption (OECD, 2008b).

13. The magnitude of the drag on consumption growth from financial wealth effects in the current episode compared with that following the bursting of the high-tech bubble at the beginning of the decade is much larger for Japan and the euro area, but not for the United States and United Kingdom. Nevertheless, the total drag from wealth effects could be longer-lasting for the United States and larger for the United Kingdom this time because housing wealth effects are reinforcing the effect of the decline in financial wealth rather than offsetting them as they did during the previous downturn.

Figure 8a. Housing, financial and total wealth effects in the United States

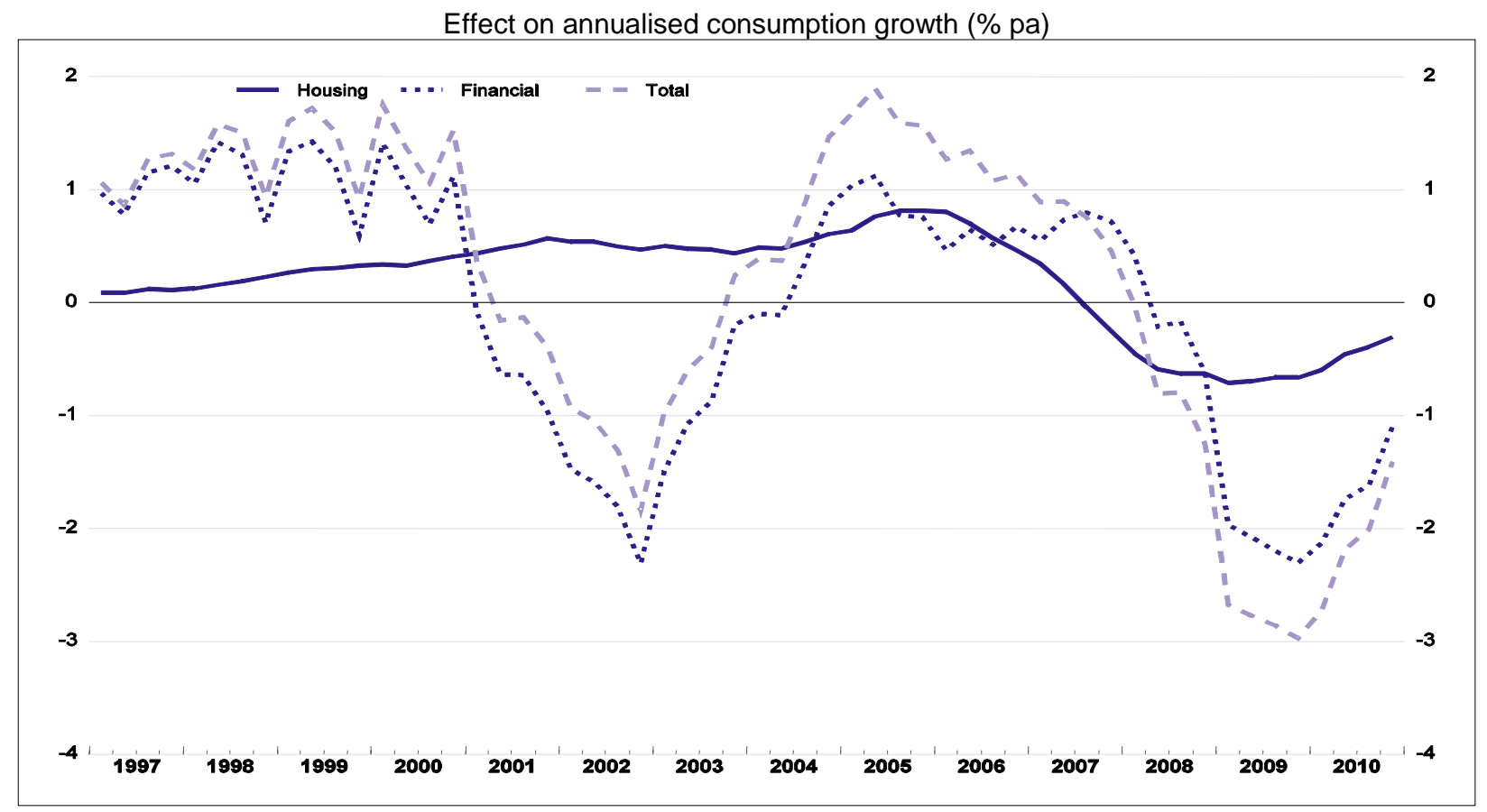

Note: Financial wealth effects are projected as in Figure 7. Housing wealth effects are projected assuming real house prices fall by $6.5 \%$ to the end of 2008 and a further $4 \%$ to the end of 2009 , with the response of consumption to housing wealth assumed to be the same as for a similar change in financial wealth.

Source: US Federal Reserve Bank; and OECD Economic Outlook 84 database.

6. Muellbauer $(2007,2008)$ provides further evidence in support of a collateral effect with econometric work that suggests that the effect of housing on consumption in the United States and the United Kingdom has varied over time depending on the degree to which the mortgage market has been liberalised. 
Figure 8b. Housing, financial and total wealth effects in the United Kingdom

Effect on annualised consumption growth (\% pa)

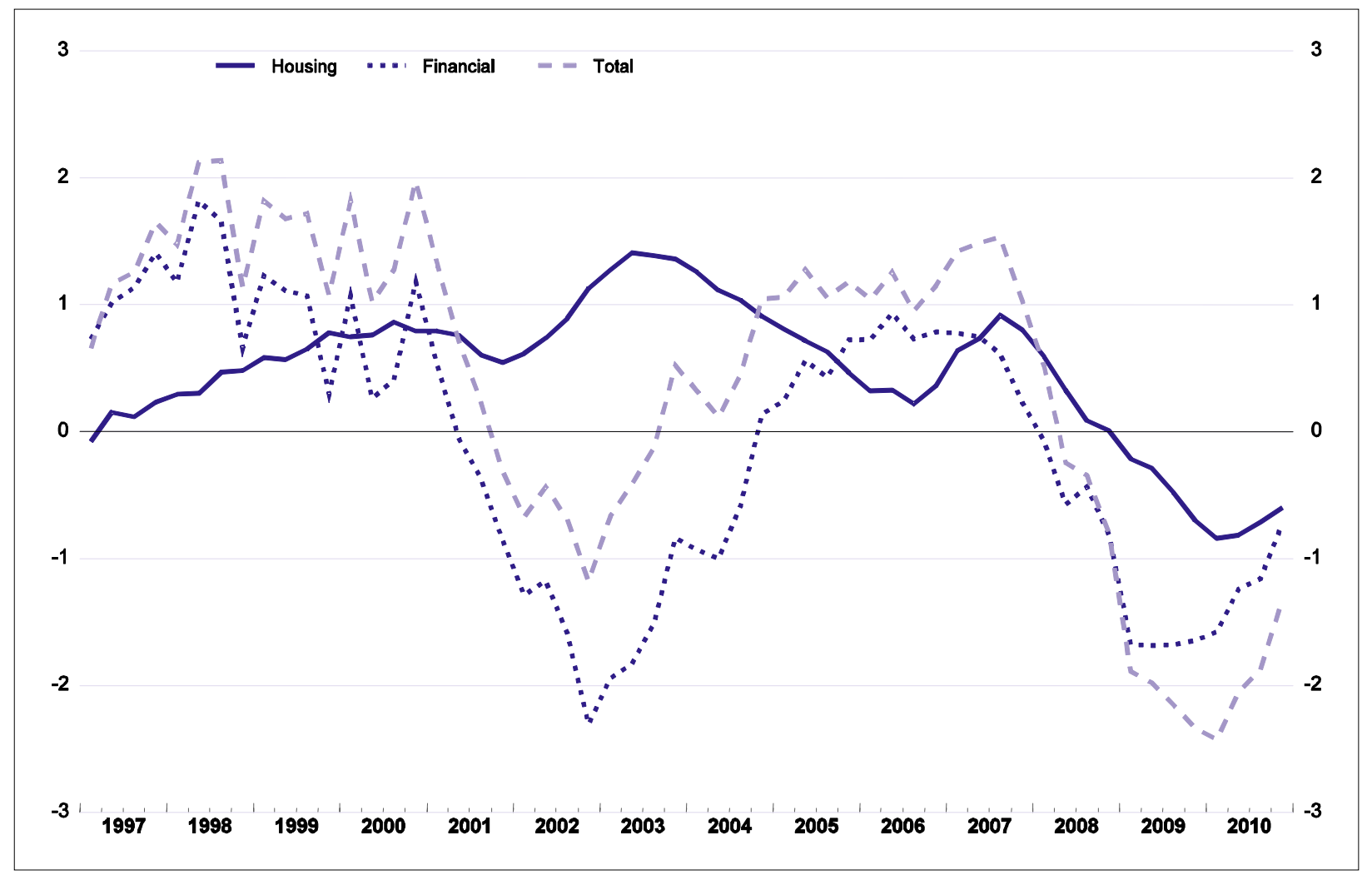

Note: Financial wealth effects are projected as in Figure 7. Housing wealth effects are projected by assuming house prices fall $12 \%$ to the end of 2009, with the response of consumption to housing wealth assumed to be the same as for a similar change in financial wealth.

Source: Office of National Statistics of the United Kingdom; and OECD Economic Outlook 84 database.

\section{Corporate bond yield spreads}

14. During periods of financial stress, the interest rate on corporate bonds may be a better indicator of the marginal cost of external finance paid by corporations than reported bank lending rates. In these circumstances, banks may have an incentive not to increase lending rates too sharply, to avoid adverse selection as strong borrowers leave the market while riskier ones remain. Instead banks may be more discriminating in respect of their lending standards. Reflecting the argument that the interest rate on corporate bonds may be a better indicator of the marginal cost of external finance, a measure of bond spreads is used in the construction of the financial conditions indicator.

15. An important data limitation is that data on the spreads of high yield corporate bonds are not available over a sufficiently long period in the United Kingdom and Japan, so investment grade (BBB-rated) bond spreads, with which they are highly correlated over the common sample, are used instead. The re-pricing of risk triggered by the crisis has resulted in a surge in corporate bond spreads. Both types of spreads have increased steeply, with a striking correspondence between the euro area, United States and United Kingdom (Figures 9 and 10). 
Figure 9. High yield spreads have reached record levels

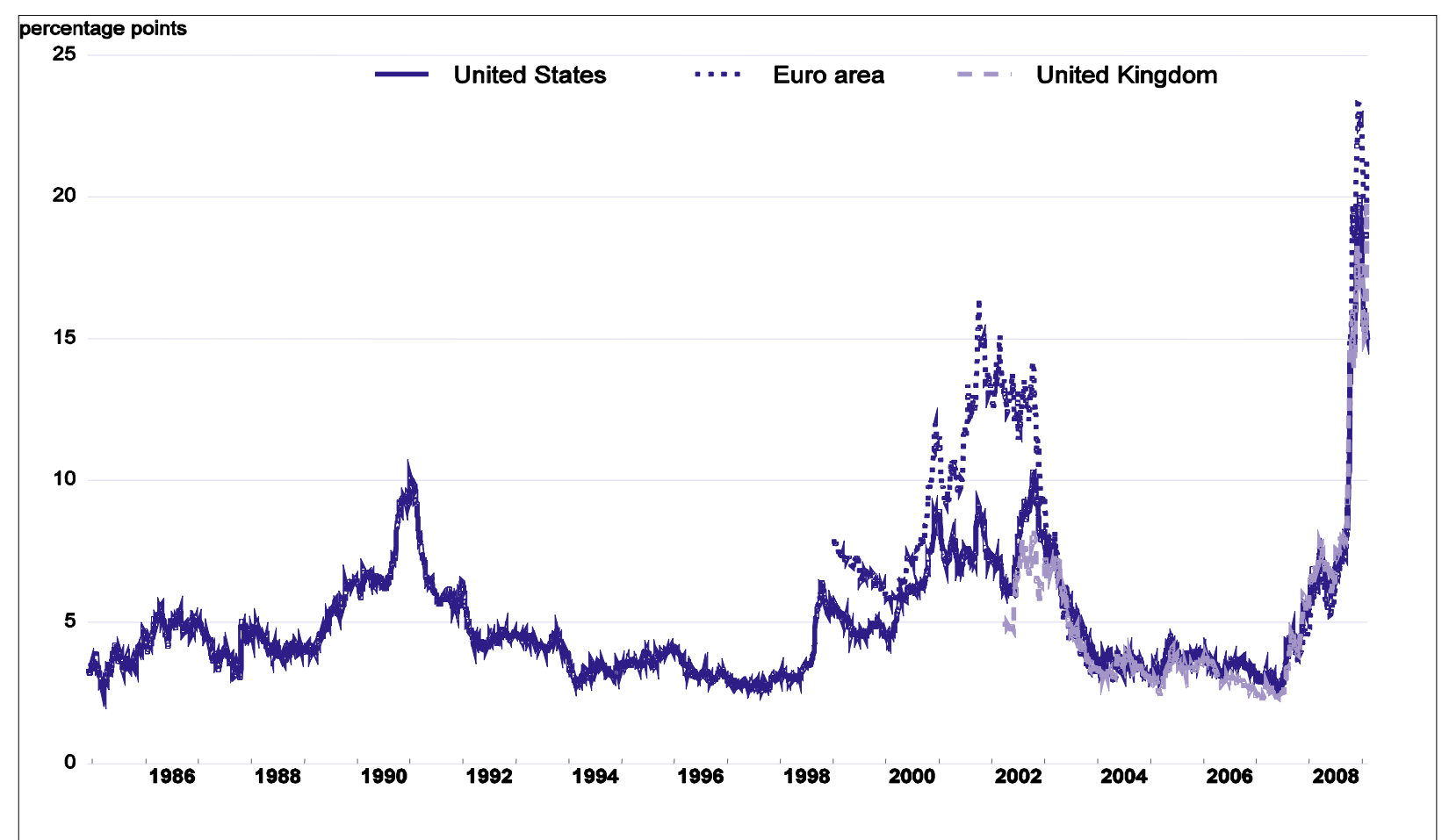

Note: Spreads of high yield bonds (Merril Lynch indices) over government bond yields (10-years benchmark bonds).

Source: Datastream; and OECD calculations.

Figure 10. Investment grade bond spreads have also surged

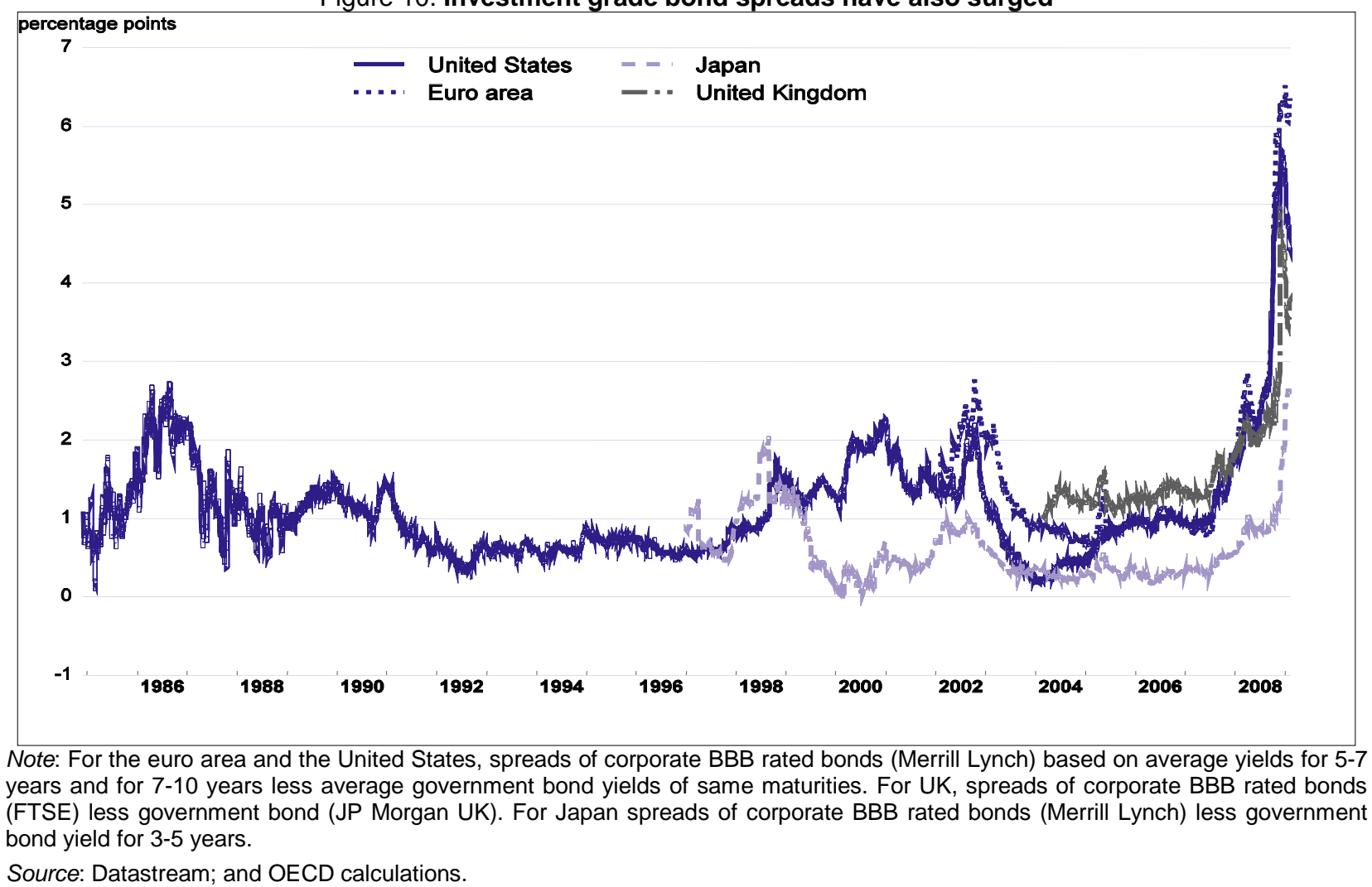




\section{Constructing FCIs for the United States, euro area, Japan and the United Kingdom}

\section{An FCI for the United States provides a benchmark}

16. A financial conditions index for the United States including real short-term interest rates, real long-term interest rates, the real effective exchange rate, bond spreads, stock market capitalisation and credit standards is described in Guichard and Turner (2008). The weight of each variable in the FCI was based on the estimated relative effect of a one-unit change in that variable on US GDP after four to six quarters, a horizon chosen because of its relevance to monetary policy. The weights were derived from econometric analysis, in some cases supplemented with coefficients calibrated from large-scale macroeconomic models simulations. In particular, estimations (VAR and reduced form) were carried out on quarterly data spanning the period 1990Q4 to 2007Q3. Because of the problems of simultaneity and causality which may particularly bias the weight of the stock market variable from the reduced form, the weight has instead been calibrated on the basis of a " $31 / 2$ cents" wealth effect on consumption (similar to that operating in the Federal Reserve's FRB/US model). A weight was also imposed on the real exchange rate, consistent with the weight that has been used by the OECD in the calculation of a Monetary Conditions Index and which has been derived from large-scale macro model simulations ${ }^{7}$.

\section{Calibration of the FCIs for the euro area, Japan and United Kingdom}

17. The extension of the FCI to other countries is mainly based on judgemental calibration using the existing US indicator as a reference point. This approach was preferred to placing greater reliance on estimation of VAR or reduced form equations, particularly because of the shorter sample period (especially for the euro area) available for estimation and because reliance on single-country estimation results may lead to counter-intuitive cross-country comparisons, although results from VAR estimations presented in the next section for the euro area, Japan and the United Kingdom are quite consistent with the calibration. The weights used in constructing the FCIs are shown in Table 2.

18. These weights have been derived on the following basis:

- Policy rates and interest rates on long-term government bonds. The OECD's new global model, (Hervé et al., 2009) like most other large-scale macro models, tends to suggest that activity in the United States is more interest rate sensitive than in other main OECD countries/regions, while differences among the latter are smaller. On the other hand, the first-year effects on activity of a change in short-term policy rates are similar for the United States and the euro area, based on comparisons between the FRB-US model and the ECB's area-wide model reported in Angeloni et al. (2003b), although larger effects emerge for the United States in the second year of the simulation. A recent study assessing the strength of the interest rate transmission mechanism in the United Kingdom and the euro area, concluded that it was probably stronger in the former (Her Majesty's Treasury, 2003). The working assumption underpinning the construction of the indices in this paper is that the interest rate sensitivity of activity is one-third lower in the euro area and Japan compared to the United States and the United Kingdom.

7. Two changes have been made to the FCI index for the United States since the work described in Guichard and Turner (2008). First, the index is expressed directly in terms of the estimated effect on GDP (again four to six quarters ahead) rather than in terms of interest rate equivalents. Apart from a re-scaling of the index an important consequence of this revision is to change its sign; a tightening in financial conditions is now indicated by a fall in the index. Second, wealth effects are related to household financial and housing wealth (normalised on personal disposable income) rather than stock market capitalisation. This better reflects the wealth effects for which this variable is calibrated and allows for the inclusion of effects from housing wealth. 
Table 2. Weights used in the construction of FCls

\begin{tabular}{|c|c|c|c|c|}
\hline & $\begin{array}{l}\text { United } \\
\text { States }\end{array}$ & Japan & $\begin{array}{l}\text { Euro } \\
\text { area }\end{array}$ & $\begin{array}{c}\text { United } \\
\text { Kingdom }\end{array}$ \\
\hline \multirow[t]{2}{*}{ Credit conditions $^{1}$ (net \% of survey response) } & -0.03 & -0.07 & -0.03 & -0.31 \\
\hline & $(24.7)$ & $(14.6)$ & (29.2) & $(2.4)$ \\
\hline \multirow[t]{2}{*}{ Corporate bond spreads ( $\%$ points) } & -0.28 & -1.21 & -0.16 & -0.91 \\
\hline & $(2.26)$ & $(0.35)$ & (3.92) & $(0.83)$ \\
\hline \multirow[t]{2}{*}{ Real short rates (\% points) } & -0.18 & -0.12 & -0.12 & -0.18 \\
\hline & $(1.82)$ & $(0.64)$ & $(1.08)$ & $(1.16)$ \\
\hline \multirow[t]{2}{*}{ Real long rates (\% points) } & -0.59 & -0.38 & -0.38 & -0.59 \\
\hline & (1.24) & $(0.74)$ & $(0.75)$ & $(0.98)$ \\
\hline \multirow[t]{2}{*}{ Real exchange rate (index, 1.0 in base year) } & -0.09 & -0.09 & -0.12 & -0.18 \\
\hline & $(0.07)$ & $(0.12)$ & $(0.08)$ & $(0.07)$ \\
\hline \multirow[t]{2}{*}{ Households wealth ${ }^{2}$ ( $\%$ of GDP) } & 0.018 & 0.015 & 0.016 & 0.016 \\
\hline & (35.6) & (39.7) & $(13.7)$ & $(85.5)$ \\
\hline \multicolumn{5}{|c|}{$\begin{array}{l}\text { 1. Net \% of survey response reporting tighter bank lending conditions. For the United States and euro area this is } \\
\text { based on a survey addressed to banks, but for Japan and the United Kingdom it is based surveys addressed to } \\
\text { businesses (see text for details). }\end{array}$} \\
\hline \multicolumn{5}{|c|}{ 2. Financial wealth and for the United Sates and United Kingdom also housing wealth. } \\
\hline \multicolumn{5}{|c|}{ Note: Standard errors for each variable over the $\mathrm{FCl}$ sample are reported in brackets. } \\
\hline \multicolumn{5}{|l|}{ Source: OECD calculations. } \\
\hline
\end{tabular}

- The real exchange rate. The OECD's new global model suggests that a $10 \%$ effective depreciation of the exchange rate leads to a stimulus to GDP of about $3 / 4$ percentage point for Japan and the United States after four to six quarters and about $1 \%$ for the euro area, with this ranking partly reflecting the weight of trade in GDP. A comparison of macro model simulation results from the Federal Reserve's FRB-US model and ECB's Area-Wide Model, confirms that GDP is more sensitive to the exchange rate in the euro area than in the United States (Angeloni et al., 2003a). By the same token the effect of a depreciation of the effective exchange rate in a smaller more open economy, such as that of the United Kingdom, will have a larger immediate effect on activity because of the greater share of trade in GDP, as borne out by other macro model simulations (Dalsgaard et al., 2001). The calibration adopted takes the results of previous work on the US FCI as given for the United States, the effect of the real exchange rate on GDP is assumed to be identical in Japan, one-third larger in the euro area and almost double in the United Kingdom.

- Wealth effects from changes in financial wealth are calibrated on the basis of a common marginal propensity to consume out of wealth of 0.04 , being close to the estimate used by the Federal Reserve Board for the United States (OECD, 2008a) as well as to an estimate for the euro area from recent empirical work by the Secretariat (OECD, 2009). It is further assumed that effects from housing wealth are only present in the United States and United Kingdom and not Japan or the euro area, as discussed in the main text.

- Credit standards are calibrated by taking the weight derived from previous work on the US FCI as given for the United States and for other countries adjusting the weight for the relative importance of bank loans in external finance. According to the OECD annual financial accounts, over the past decade bank credit represented on average $17 \%$ of external non-financial corporation financing in the United States, 43\% in Japan, 21\% in the euro area and 26\% in the United Kingdom. This implies a much larger weight for Japan than the United States and slightly larger weight in the euro area. The weights are adjusted to reflect the relative variability of the underlying survey data, although in practice this is very similar for the US, euro area and Japanese surveys. The larger apparent weight for credit standards in the United Kingdom mainly 
reflects the lower variability in the survey responses, which are scaled up to reflect the more limited range in survey responses compared to the US survey.

- Corporate bond spreads are calibrated by taking the weight derived from previous work on the US FCI as given for the United States and for other countries adjusting the weight for the relative importance of the corporate bond market in external finance, which in particular implies a lower weight for the euro area than for the other countries. There is empirical evidence on the relationship between spreads and real activity, although it mostly relates to the United States. ${ }^{8}$ Previous empirical work by the OECD underlying the financial conditions index for the United States suggests that a 100 basis points widening of the high-yield spread reduces GDP by about $1 / 4$ percentage point after four to six quarters (Guichard and Turner, 2008). This calibration results in a lower weight for other countries relative to that for the United States; the weight for the euro area is only $60 \%$ of the US weight, $80 \%$ for Japan and $85 \%$ for the United Kingdom. This may, however, underestimate the importance of corporate bond spreads, if they are indicative of the increased cost of raising capital for businesses more generally.

\section{Robustness testing of the calibrated FCIs}

19. This section describes attempts to check the calibration both through the results from estimating VARs and reduced form equations as well as by ex post testing of the FCIs in reduced form equations explaining the output gap.

\section{Comparing the results from VAR analysis with the FCI calibration}

20. The effect of the FCI financial variables on GDP was estimated using VARs in order to check how close the results are to the calibrations used in constructing the FCIs. VARs have the advantage of taking into account the feedback between all variables, which may be particularly important when dealing with financial variables. That said, the VAR specification cannot distinguish between the link between GDP and a variable caused by a causal relationship and caused by anticipation. For example, lower equity prices might reflect expectations of a future declines in GDP. Moreover a major limitation to this analysis is the very short sample available in the euro area (credit standards start in 2003) and even in Japan (spreads available are only available from 1997). ${ }^{9}$

8. Gertler and Lown (2000) and Mody and Taylor (2003) show that the high-yield bond spread has a significant explanatory power for the US business cycle. Chan-Lau and Ivaschenko (2001) found similar results using investment grade bonds and argue, in contrast to Gertler and Lown (2000), that such spreads better reflect economic fundamentals such as expected investment returns. De Bondt (2002) found an effect of BBB-rated bonds on euro area GDP, such that a temporary increase in the BBB-rated bond spread by around 100 basis points results in a decline of around 11/4 percentage points in GDP after 9-12 months.

9. The VARs include GDP growth, core inflation, the underlying fiscal deficit and the financial variables included in the FCI except long-term interest rates that were never found to be significant. Oil prices and in some cases external demand are also included as exogenous variables. The VARs are estimated on quarterly data and include one lag for each variable for the euro area and the United Kingdom, two for the United States, three for Japan. In the case of the United Kingdom, one VAR has been estimated on a long sample without the wealth and spreads variables and a second on a shorter sample including these variables. Once the estimated VAR has passed standard tests for stability and normality of residuals, generalised impulse functions are calculated following the approach proposed by Pesaran and Shin (1998) (and used by Gauthier et al. (2004) in their construction of an FCI for Canada). This approach has the merit that responses to shocks are invariant to the ordering of the variables. This feature is especially important when dealing with financial series for which there is no clear theory-based ordering of the variables that could be used, for example, in a standard Choleski factorisation. 
21. The main results of the VAR models and a comparison with the FCI calibration is presented in Table 3. Although there are inevitably differences between the VAR results and the FCI calibration, an encouraging finding is that corporate bond spreads as well as the proxy variables for bank lending all have substantial effects on GDP which are mostly of a similar order of magnitude to the calibration. Other results, particularly relating to the effects of financial wealth, appear more at odds with the calibration, although their wide dispersion across countries might be taken as further underlining the case for calibrating the weights.

Table 3 Comparison of the weights used in the construction of FCls with the VAR results

\begin{tabular}{|c|c|c|c|c|c|c|c|c|c|c|c|}
\hline & \multicolumn{3}{|c|}{ United States } & \multicolumn{2}{|c|}{ Japan } & \multicolumn{3}{|c|}{ Euro } & \multicolumn{3}{|c|}{ United Kingdom } \\
\hline & $\mathrm{FCl}$ & VAR1 & VAR2 & $\mathrm{FCl}$ & VAR & $\mathrm{FCl}$ & VAR1 & VAR2 & $\mathrm{FCl}$ & VAR1 & VAR2 \\
\hline Credit conditions & -0.03 & -0.03 & -0.03 & -0.07 & -0.11 & -0.03 & -0.04 & -0.02 & -0.31 & -0.12 & -0.01 \\
\hline Corporate bond spreads & -0.28 & -0.29 & -0.29 & -1.21 & -1.21 & -0.16 & -0.19 & -0.16 & -0.91 & na & -1.10 \\
\hline Real short rates & -0.18 & -0.30 & -0.48 & -0.12 & -0.88 & -0.12 & -0.28 & -0.01 & -0.18 & 0.00 & -0.14 \\
\hline Real long rates & -0.59 & na & na & -0.38 & na & -0.38 & na & na & -0.59 & na & na \\
\hline Real exchange rate & -0.09 & -0.12 & -0.18 & -0.09 & -0.08 & -0.12 & -0.42 & -0.27 & -0.18 & -0.07 & 0.06 \\
\hline Households wealth & 0.02 & 0.000 & 0.000 & 0.01 & 0.00 & 0.02 & na & 0.001 & 0.02 & na & 0.04 \\
\hline Estimation period & & 90:4-07: & $90: 4-07: 3$ & & $97: 4-08: 3$ & & 03:1-08: & 03:1-08:3 & & 81:3-08: & $95: 3-08: 2$ \\
\hline
\end{tabular}

Note: Estimated percentage effect on GDP after 4-6 quarters (3-5 quarters for credit conditions in Japan and the United Kingdom). The difference between VAR 1 and VAR 2 in the United States is the introduction of the fiscal stance as an endogenous variable. For all the other countries, the fiscal stance is included as one of the endogenous variables. Exogenous variables include the price of oil for all countries and external demand for the United States and Japan.

Source: OECD calculations.

22. In more detail, the main results are as follows:

- Corporate bond spreads have a significant impact on GDP growth that is quite close to the calibrated impact retained in the FCI construction. For the United States and the euro area, a 100 basis points widening of the high-yield spread was found to reduce GDP by about 0.3 and 0.2 percentage points, respectively, after four to six quarters. For Japan and the United Kingdom, an increase in the BBB-rated bond spread (which has a much lower variance than the high-yield bond spread) by around 100 basis points results in a decline of around 1 percentage points in GDP after four to six quarters.

- Credit standards also have a significant impact on GDP in the United States, the euro area, Japan and to a lesser extent the United Kingdom. An impact of similar magnitude to that in the United States was found for the euro area, although given the small sample size the results are much less robust. In the case of Japan, the Tankan survey responses of large companies to a question relating to bank's lending attitudes was also found to have a significant impact on GDP. A net 10 percentage points tightening in the survey response on bank lending attitudes reduces GDP by about 1 percentage point after three to five quarters. For these three countries, the estimated results tend to support the calibrated effects adopted in the construction of the FCIs. The estimated impact of credit conditions in the United Kingdom is found to be smaller than the one assumed in the calibration of the FCI and only significant when the longer sample size was used. This suggests that the weight of credit conditions may be overstated in the UK FCI.

- Wealth was never found to have a significant impact on GDP except for the United Kingdom. 
- As in the case of VAR estimates for the United States presented in Guichard and Turner (2008), real short-term interest rates had in several cases only a small and statistically insignificant impact on GDP.

- The estimated impact of real exchange rates is close to the one assumed for the calibration for the United States and Japan, but well above for the euro. In the United Kingdom the long sample estimation gives a much lower impact than assumed in the FCI, and the short sample gives a nonsignificant positive impact.

\section{Testing the inclusion of FCIs in reduced form output gap regressions}

23. In order to provide some ex post validation of the new indicators they were included in reduced form equations for the output gap for each of the respective countries/regions as explanatory variables along with measures of real oil prices, fiscal stimulus (measured as the change in the cyclically-adjusted government net lending expressed as percentage of GDP), and (the deviation from trend of) export market growth. The results for these explanatory variables are mixed. In particular, no role for the fiscal variable is found in any of the regressions, real oil prices are only found to be significant in the equation for the United States, although the export market growth variable is found to be significant in all equations except that for the United States.

24. The FCI variables are economically and statistically significant in all equations, with an F-test of the restriction for their joint exclusion being rejected at conventional levels of statistical significance in all equations (Table 4). Evaluating the impulse response functions for the response of GDP to a sustained unit change in the FCI indicator suggests the average change in the output gap after four to six quarters is somewhat below the $1 \%$ effect which is assumed in the calibration; for the United States it is $0.59 \%$, for the euro area $0.49 \%$, for Japan $0.52 \%$, and the United Kingdom $0.36 \%$. While confirming their explanatory power, the magnitude of the estimated impacts of the financial conditions indices on the output gap after four to six quarters suggests that the indices could exaggerate the impact of financial conditions on GDP. In view of this, index values may best be seen as providing an upper limit to the effects of financial conditions on activity. 
Table 4 Testing the significance of the financial conditions indices in reduced form output gap equations

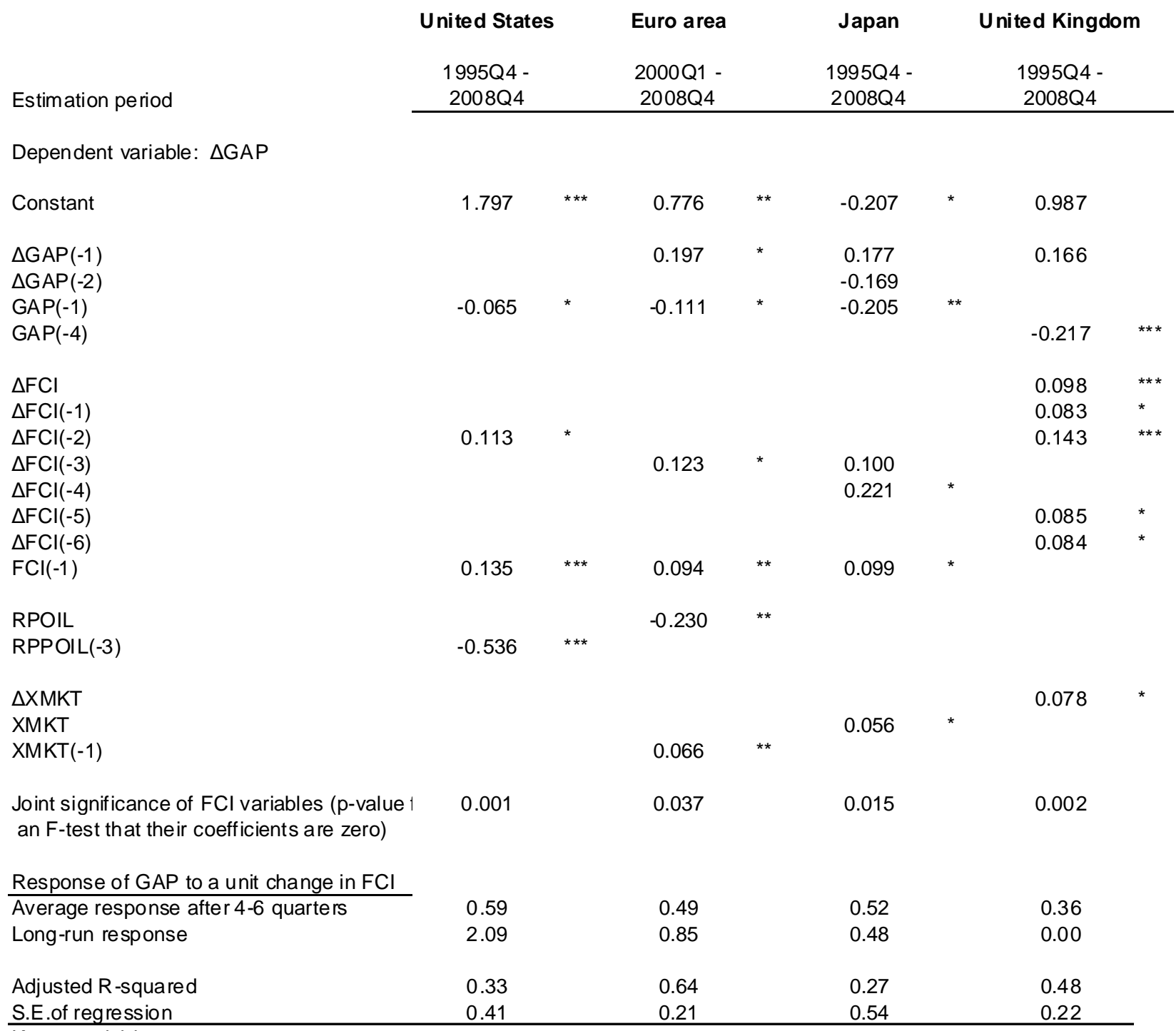

Key to variables

$\Delta$ denotes the first difference operator

GAP = Output gap.

$\mathrm{FCl}=$ Financial conditions index (see main text for details).

RPOIL = Real price of oil (logged), measured as the price of Brent oil in local currency relative to the GDP deflator.

$\mathrm{XMKT}=$ Deviation of (logged) export market growth from trend.

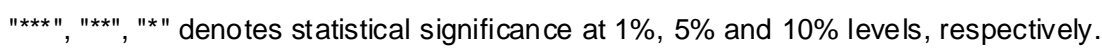

Data Sources: OECD Analytical Database unless otherwise specified. 


\section{Results: Cross-country comparisons of financial conditions during the current and previous episodes}

25. Comparisons of the FCIs across countries/regions are more meaningful in terms of their change over a given period rather than their absolute level. One reason for this is that each individual country FCI is expressed as a deviation from its historical average, but even over an extended period average financial conditions may have been different across countries, as, for example, Japan experienced a serious banking crisis during the $1990 \mathrm{~s}^{10}$.

26. The indices point to a loosening in financial conditions across all countries in the years immediately before the crisis (Figures 11a-d and Figure 12). Since the onset of financial crisis there has been a very marked worsening in financial conditions, with the most rapid rate of deterioration occurring since the third quarter of 2008.

Figure 11a. The financial conditions index ${ }^{1}$ for the United States

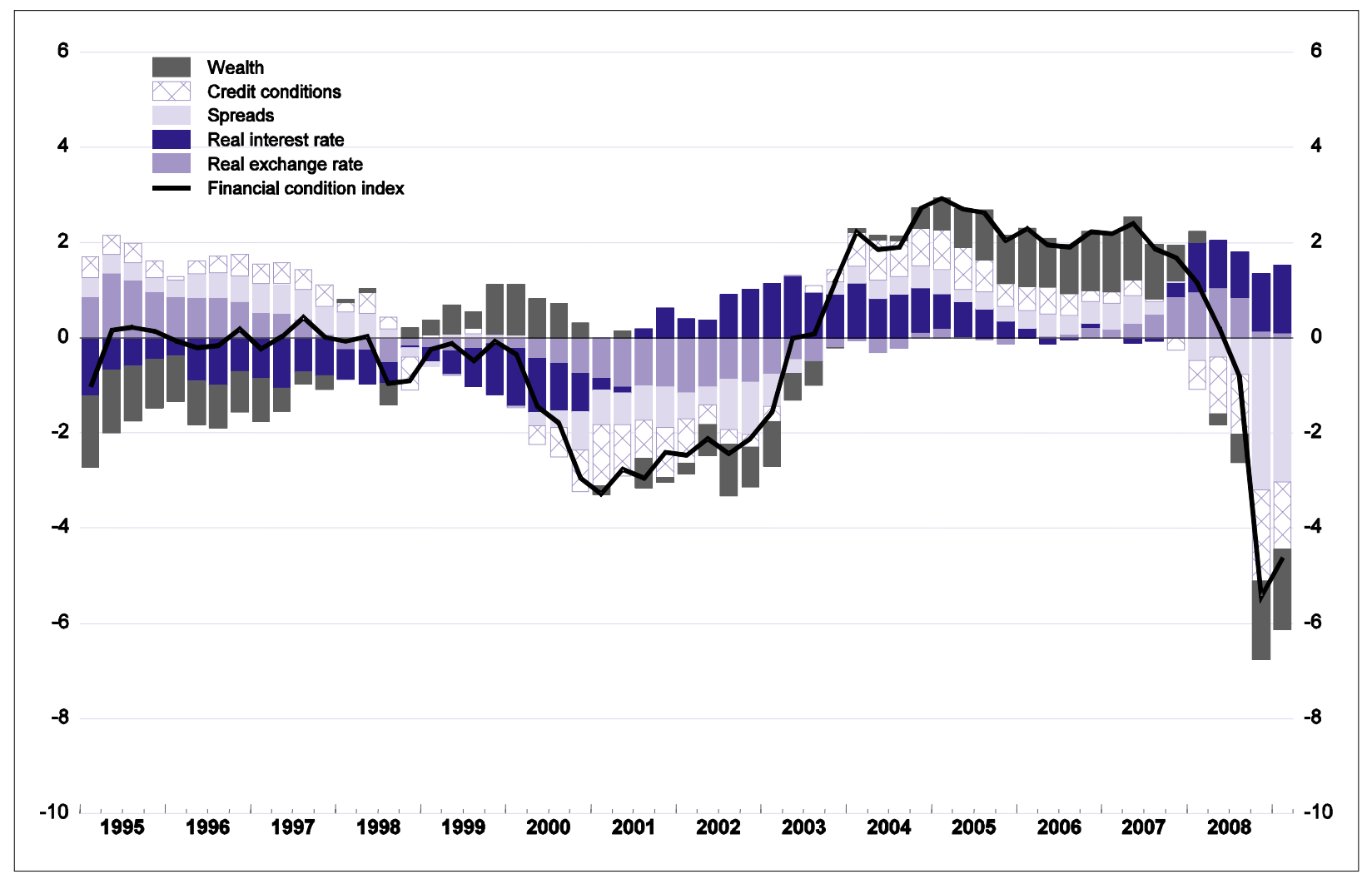

1. A unit decline in the index implies a tightening in financial conditions sufficient to produce an average reduction in the level of GDP by $1 \%$ after $4-6$ quarters.

Source: OECD Economic Outlook 84 database; Datastream; and OECD calculations.

10. An additional reason why it is difficult to compare the level of FCIs across countries/regions is that for the euro area the FCI is only constructed from 1998 rather than 1995. 


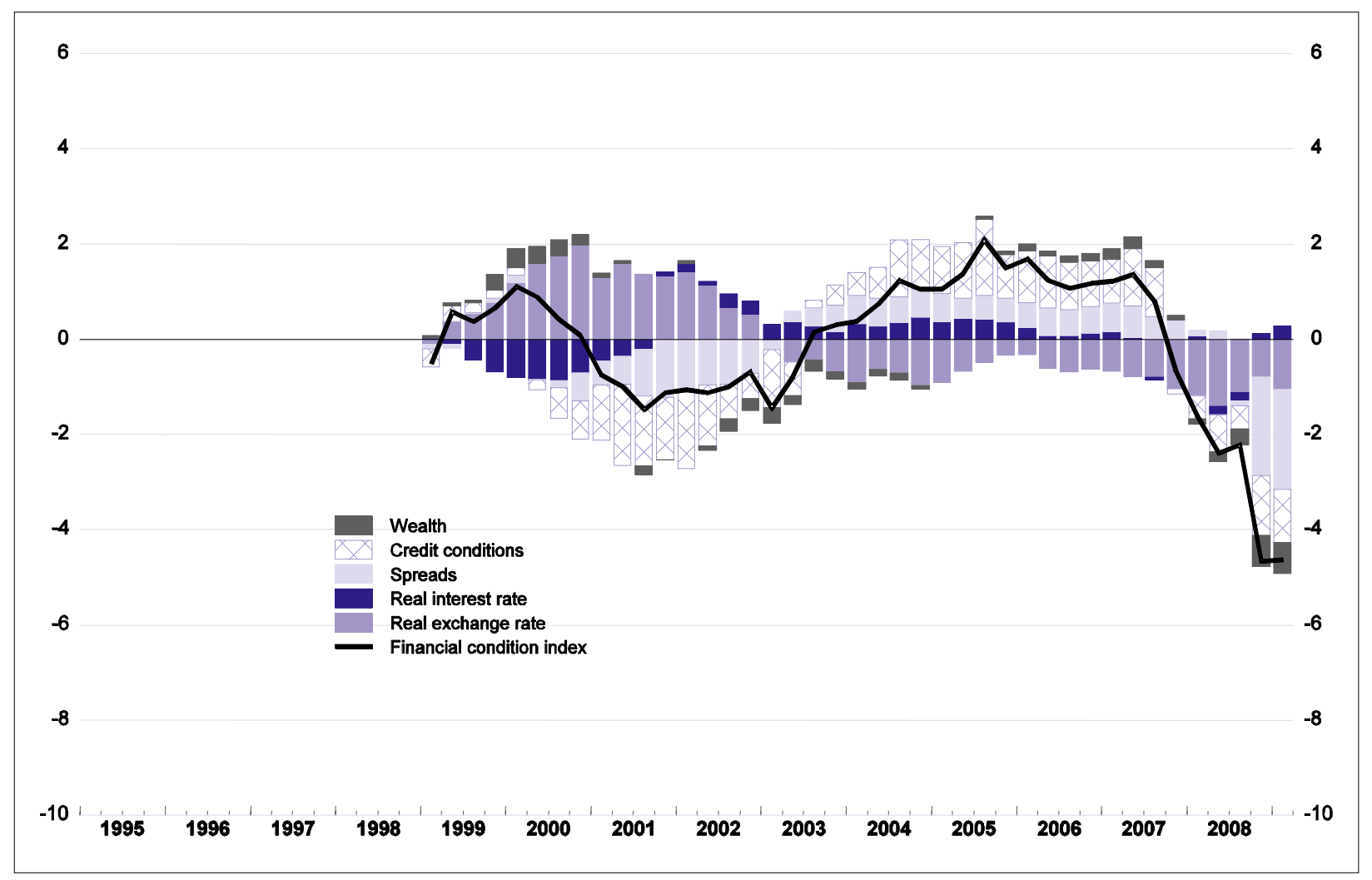

1. A unit decline in the index implies a tightening in financial conditions sufficient to produce an average reduction in the level of GDP by $1 \%$ after $4-6$ quarters.

Source: OECD Economic Outlook 84 database; Datastream; and OECD calculations.

27. However, the scale of the deterioration since mid-2007 differs across countries (Table 5): it is largest for Japan and the United States with a cumulative implied hit to real GDP of about $8 \%$ and $7 \%$, respectively; for the euro area, the impact on real GDP is about $6 \%$ and for the United Kingdom about $5 \%$. An important contribution to this ranking is the extent to which monetary conditions, that is official interest rates and the exchange rate, have been able to offset the tightening in other financial conditions. In the case of the United Kingdom the contribution of lower official interest rates and especially the depreciation of sterling have offset more than half the deterioration in other financial conditions. Conversely, for Japan the limited scope to lower official interest rates together with the recent marked appreciation of the yen has considerably exacerbated the effect of the tightening in other financial conditions. Relative to the onset of the financial crisis in mid-2007, the real exchange rate has made a smaller contribution to the change in financial conditions in the United States and euro area, although in the former case this comparison disguises the marked change in the trend movement in the US dollar since mid-2008. 


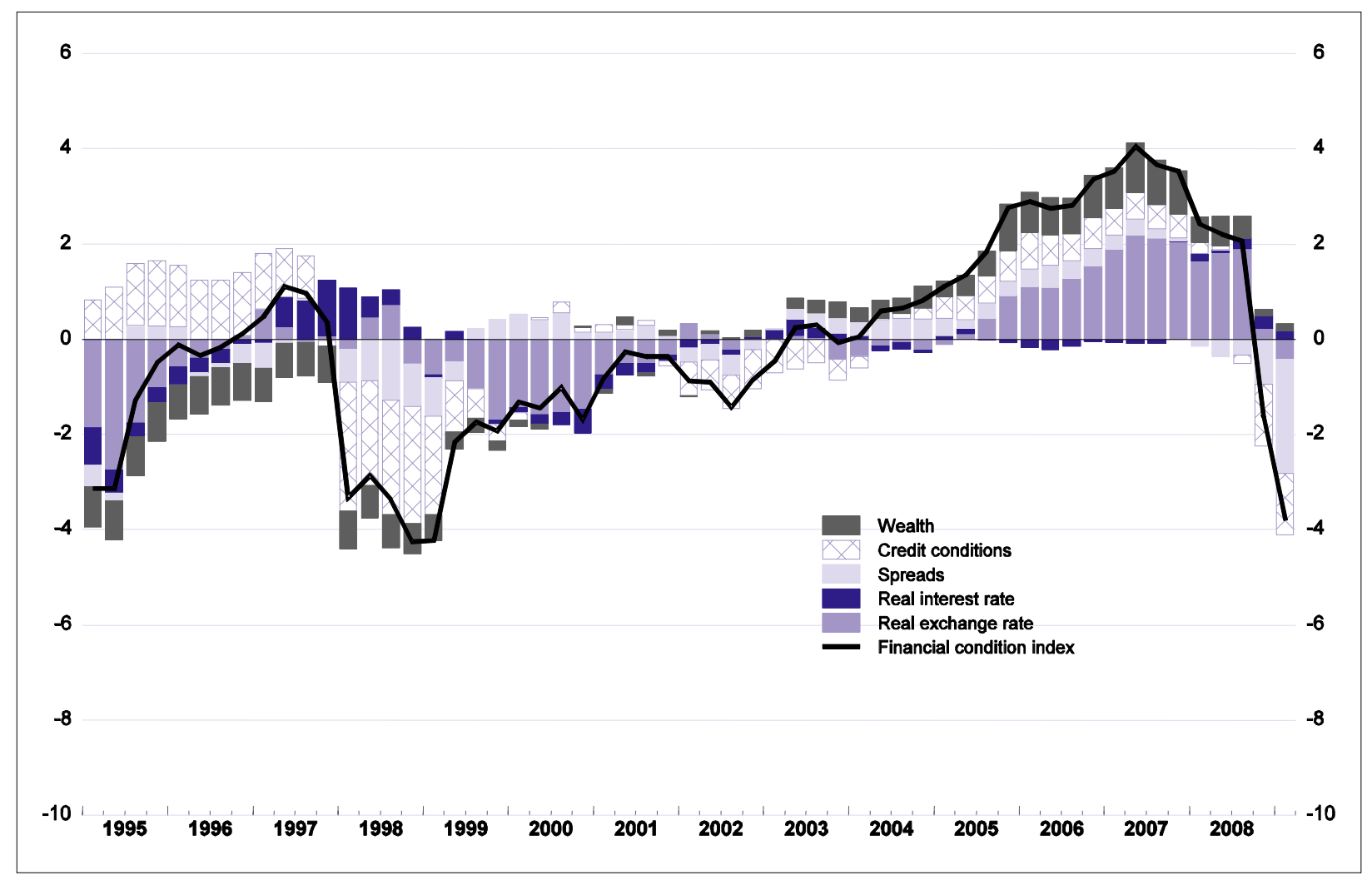

1. A unit decline in the index implies a tightening in financial conditions sufficient to produce an average reduction in the level of GDP by $1 \%$ after $4-6$ quarters.

Source: OECD Economic Outlook 84 database; Datastream; and OECD calculations.

28. The tightening of lending standards has made an important contribution to the tightening in financial conditions in all countries, and although according to FCIs this occurs only more recently for the United Kingdom and Japan this may reflect differences in the surveys used to assess credit conditions. ${ }^{11}$ The widening in corporate bond spreads is consistently one of the largest contributors to the tightening of financial conditions for all countries, especially since the third quarter of 2008. Wealth effects are somewhat greater in the United States and United Kingdom, compared to Japan and the euro area, given relatively larger equity holdings and collateral effects from falling house prices.

11. Credit standards for Japan and the United Kingdom are assessed using surveys addressed to businesses rather than banks, so it is likely that there is a recognition lag. A particular source of uncertainty relates to the magnitude of the tightening in lending standards in the United Kingdom, which reflects the strong deterioration of credit standards in the last quarter of 2008 which went beyond the previous historical experience. 


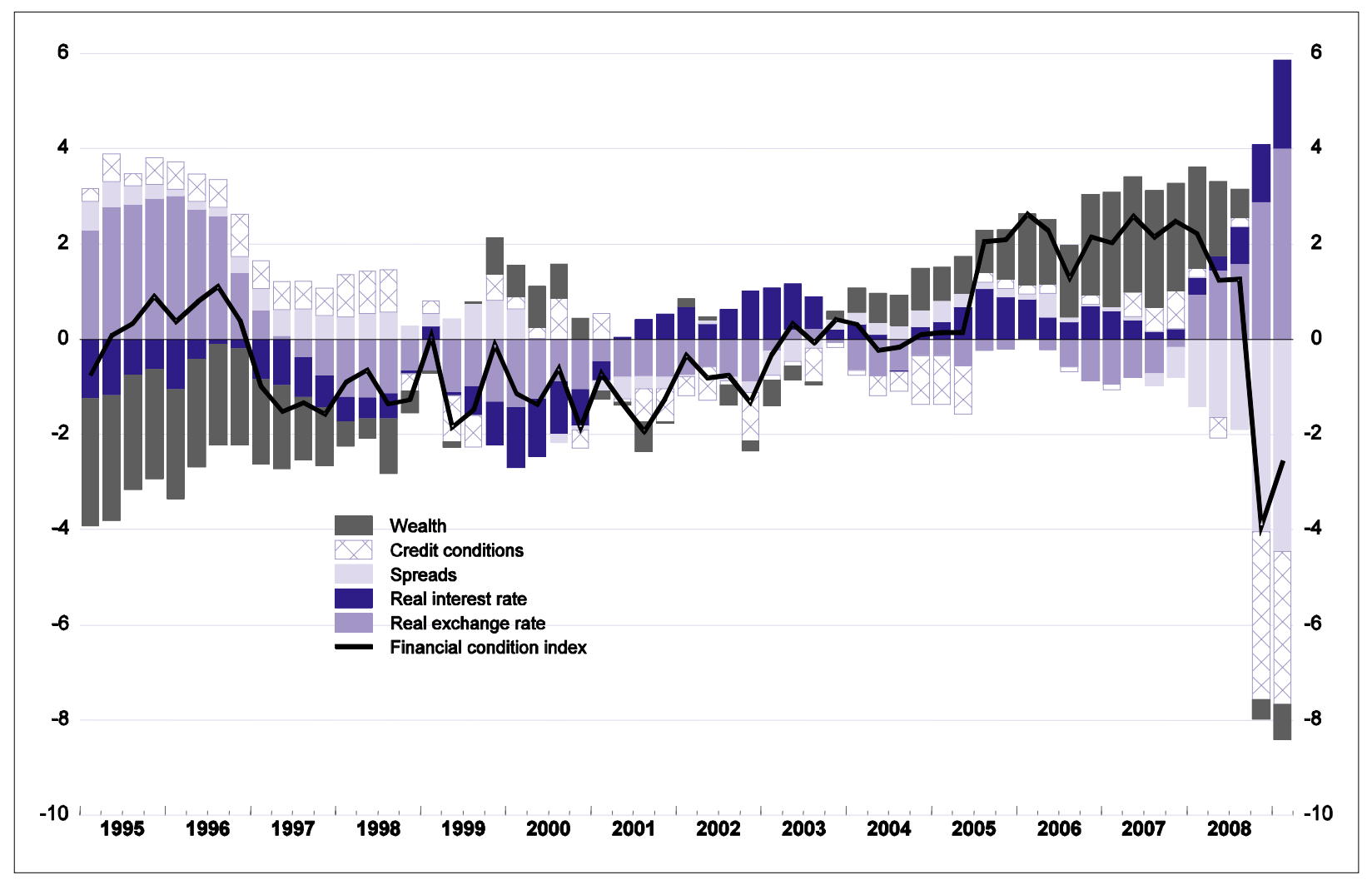

1. A unit decline in the index implies a tightening in financial conditions sufficient to produce an average reduction in the level of GDP by $1 \%$ after $4-6$ quarters.

Source: OECD Economic Outlook 84 database; Datastream; and OECD calculations.

29. Over the sample period considered (for most countries since 1995), the only historical episode where the tightening in financial conditions comes close in severity to the current episode is the banking crisis of 1997-98 in Japan. Over this period the tightening in Japan's financial conditions is estimated to have subtracted $4 \%$ from the level of GDP, mainly because of the tightening in banks' lending standards. Tighter standards also play an important role in the current crisis in the United States, United Kingdom and euro area, but bond spreads and stock markets are playing a larger role because the current crisis and shifts in attitude to risk are more global and widespread across asset classes. 
Figure 12. Comparisons of financial conditions indices ${ }^{1}$ across countries

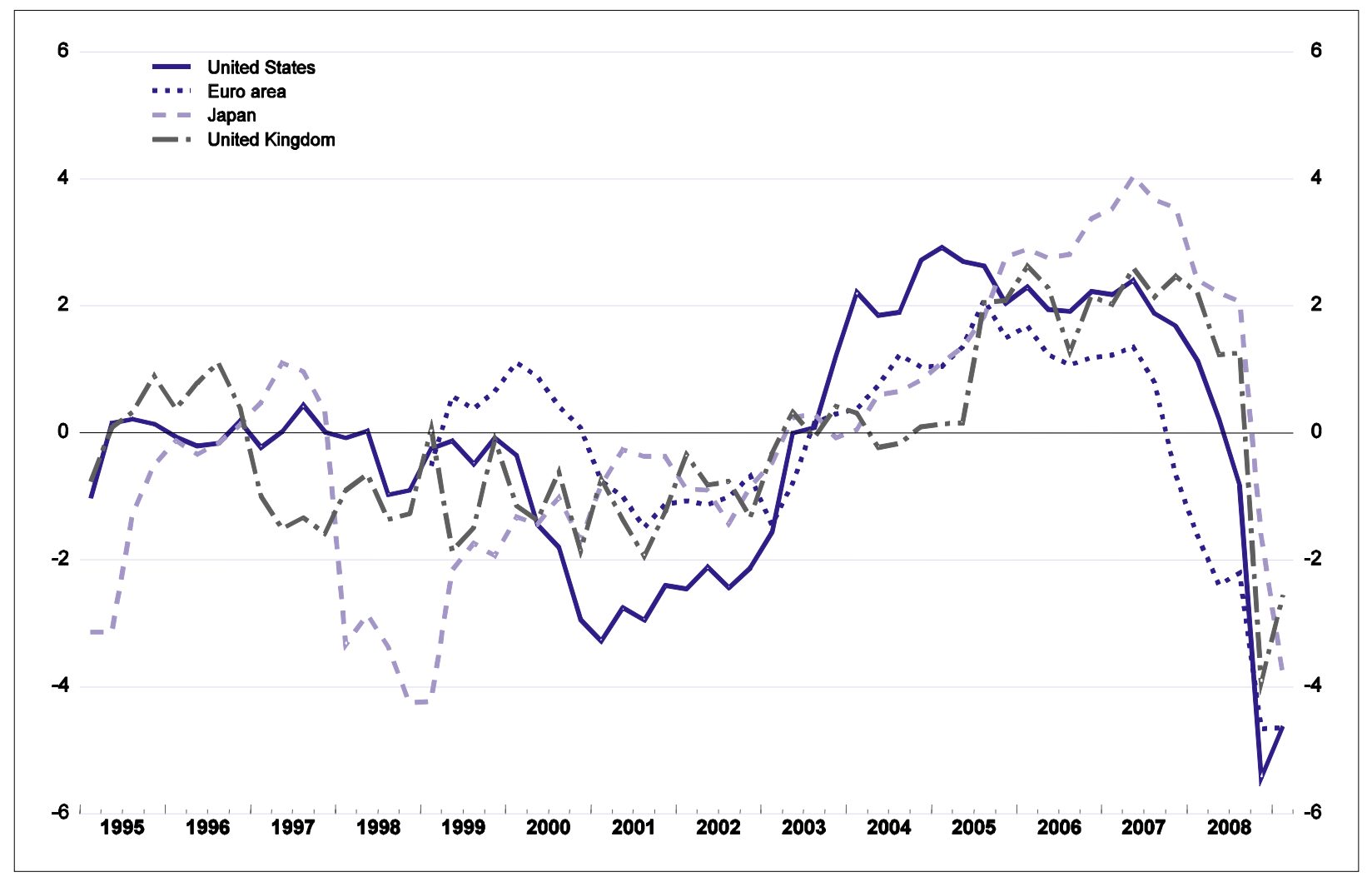

1. A unit decline in the index implies a tightening in financial conditions sufficient to produce an average reduction in the level of GDP by $1 \%$ after $4-6$ quarters.

Source: OECD Economic Outlook 84 database; Datastream; and OECD calculations.

Table 5. Accounting for the tightening in financial conditions since the onset of financial turmoil

Change in the financial conditions index 2007Q2 - 2009Q ${ }^{1}$

Wealth effects

Widening of bond spreads

Credit standards

Policy and long-term government bond rates

Real exchange rate

Total

\begin{tabular}{cccc}
$\begin{array}{c}\text { United } \\
\text { States }\end{array}$ & $\begin{array}{c}\text { Euro } \\
\text { area }\end{array}$ & Japan & $\begin{array}{c}\text { United } \\
\text { Kingdom }\end{array}$ \\
\hline-3.0 & -0.9 & -0.9 & -3.0 \\
-3.6 & -2.8 & -2.7 & -4.5 \\
-1.8 & -2.3 & -1.9 & -3.7 \\
1.5 & 0.2 & 0.3 & 1.4 \\
-0.2 & -0.3 & -2.6 & 4.8 \\
-7.0 & -6.0 & -7.8 & -5.0 \\
\hline
\end{tabular}

1. The changes are equivalent to the estimated percentage effect on GDP after 4-6 quarters.

Source OECD calculations. 


\section{The contribution of financial conditions to GDP growth}

30. This section demonstrates how the FCIs can be used to infer the implications of financial conditions for future GDP growth. It is changes in the FCI and their effect on growth over the following 12 years, the time horizon the FCIs have been explicitly designed to consider, that is the focus of this exercise. The first part describes a simple stylised simulation of a shock to the FCI on GDP growth and the output gap. The second part calculates the effect on future growth and the output gap of current financial conditions as measured by the latest FCIs for the United States, euro area, Japan and the United Kingdom.

\section{A stylised simulation}

31. Each FCI is calibrated so that a unit decline in the index implies a $1 \%$ reduction in the level of GDP after 4-6 quarters. To translate the FCI into an effect on growth, the FCI is assumed to take full effect after five quarters (the average of 4-6 quarters) with the effect gradually building up over the intervening quarters. Thus, the effect of financial conditions on the level of economic activity in the current quarter is a moving average of the FCI level in the current and previous five quarters.

32. For the purpose of the stylised simulation, GDP is assumed to be on a trend growth path with a zero output gap prior to the shock. The assumed shock is a sustained one unit fall in the FCI, while trend output growth is assumed to be unchanged as a consequence of the change in financial conditions (Figure 13). The effect of the shock is to reduce quarterly growth for 5 quarters until the level of GDP is $1 \%$ lower (relative to trend) and a corresponding output gap is opened up. Thus, growth is only temporarily affected while the economy adjusts to a $1 \%$ lower level of activity.

\section{The implications of the FCIs for future GDP growth}

33. The implications of recent changes in financial conditions for growth in the main OECD countries can be computed in the same way as for the stylised example. It should be emphasised that these calculations should be interpreted as the contributions of financial conditions to growth and not as fullyfledged forecasts, not least because the latter would also need to take into account the effect of other factors such as world trade, fiscal policy and oil prices.

34. The FCIs for the United States, euro area, Japan and the United Kingdom are translated into their corresponding contributions to annual (year-on-year) GDP growth and the output gap (Figure 14) under an assumed future path for the FCIs. The assumed path holds the FCI constant at 2009 Q1 values through to 2009 Q4, after which a gradual normalisation in bank lending, bond spreads and interest rates is assumed so that their contributions to the FCI by 2010 Q4 is zero. The contribution of asset prices, and therefore wealth and the exchange rate, to financial conditions are assumed to stay at current (2009 Q1) levels given the inherent difficulty in forecasting them. To ease interpretation and make comparisons with history easier the contribution of financial conditions is added to the potential growth rate (the latter as estimated in OECD Economic Outlook No.84).

35. In all four regions/countries, current and assumed future financial conditions generate a continuous fall in the year-on-year GDP growth rate to the third or fourth quarter of 2009. Although there is a subsequent pick up in the growth rate contribution it is not until the second half of 2010 that it is calculated to exceed the potential growth rate and so begin to close the output gap. The size of the implied output gaps would be larger than any previously calculated by the OECD for the euro area, Japan and the United Kingdom (for the euro area output gap calculations are available since 1991 and for the other two countries since 1970). For the United States the implied output gap is marginally smaller than the output gap of 7\% experienced at the end of 1982. 
Figure 13. Simulation of a sustained fall in the $\mathrm{FCl}$

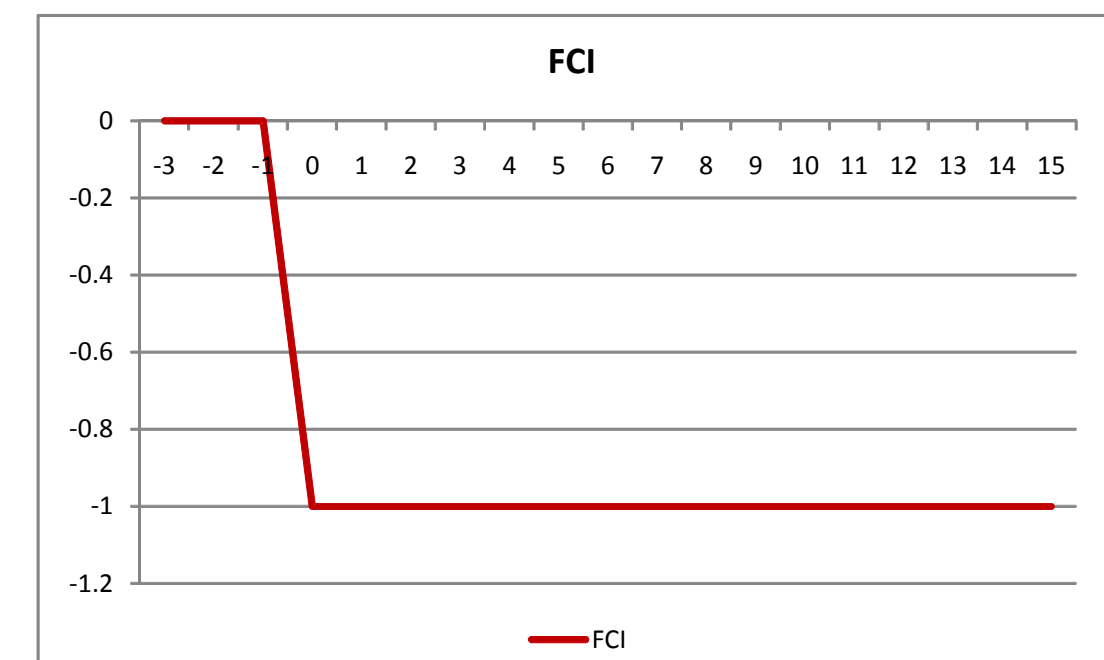

Real GDP Quarterly Growth

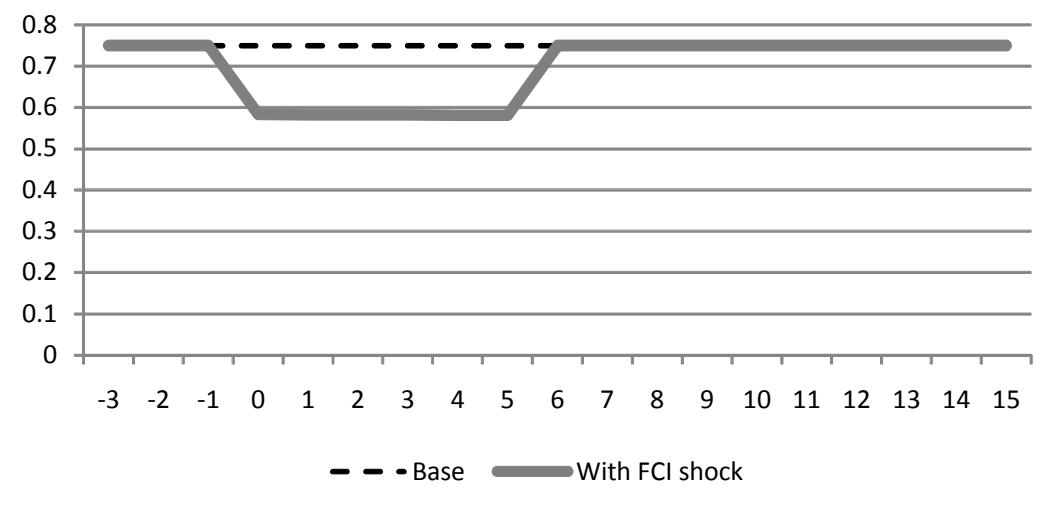

Source:

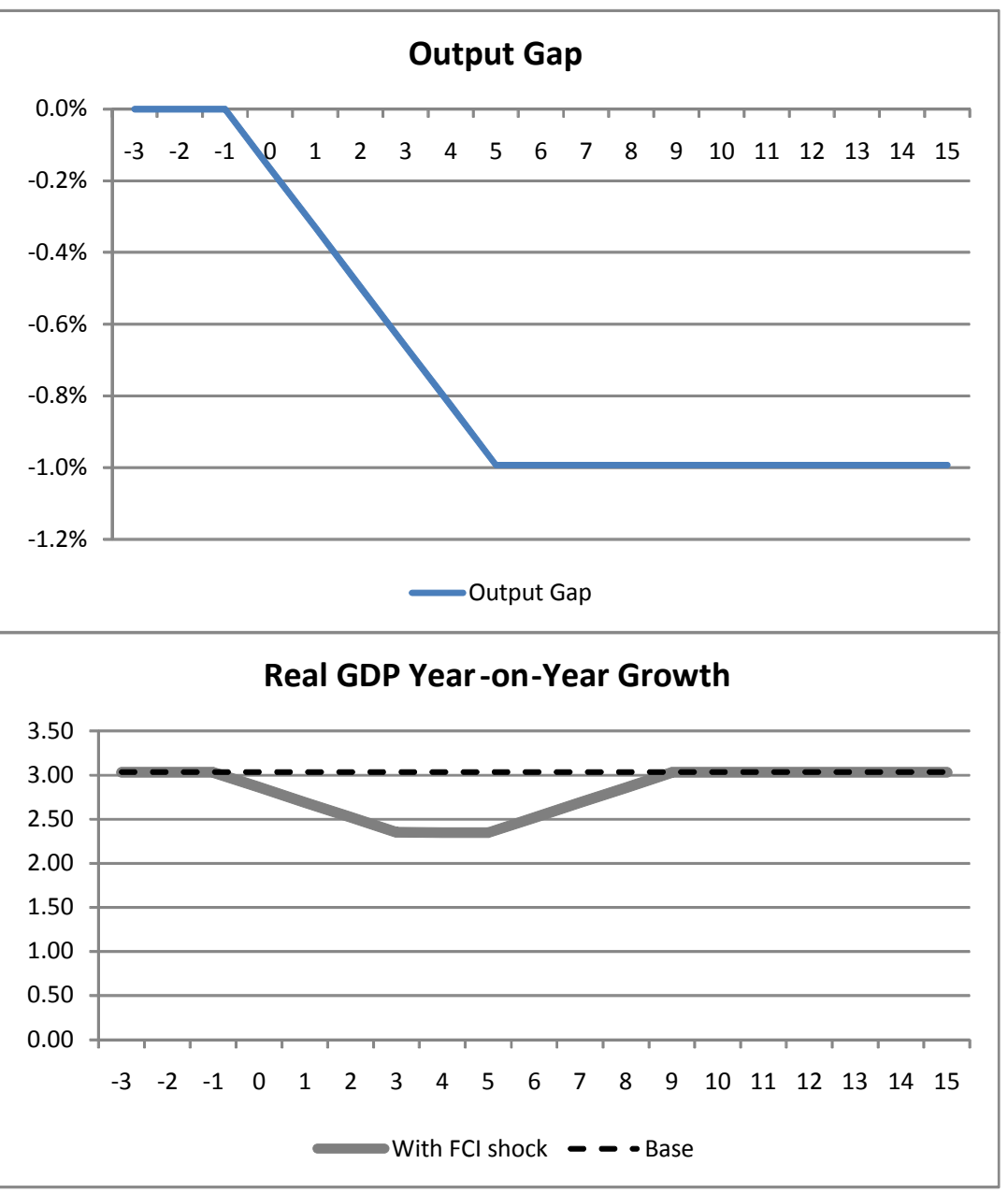

OECD 
Figure 14. Implications of the FCls for GDP growth and the output gap

United States

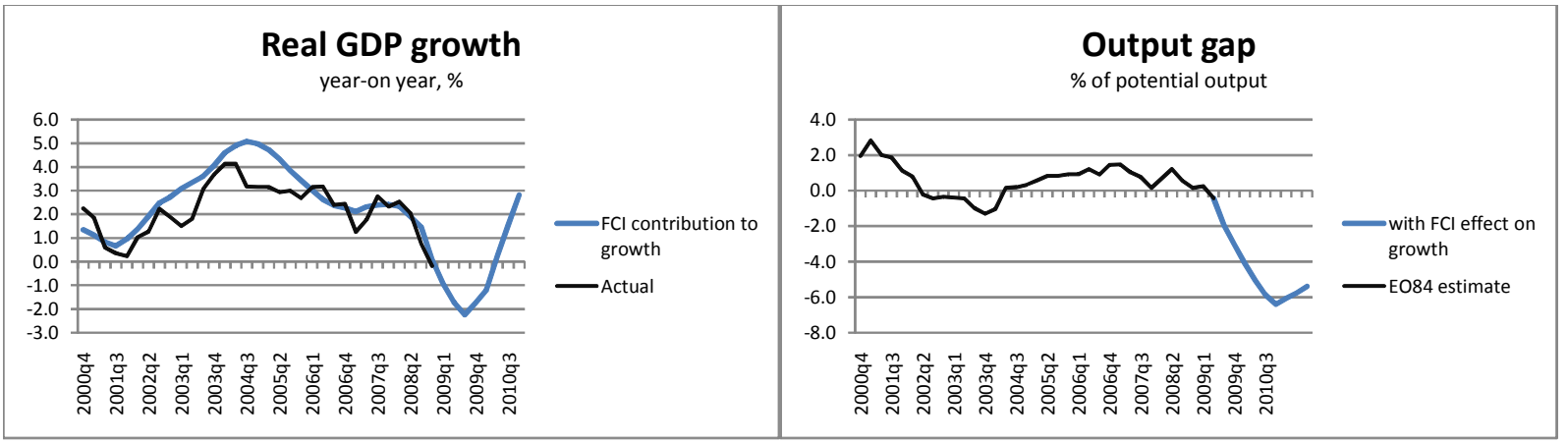

Euro area
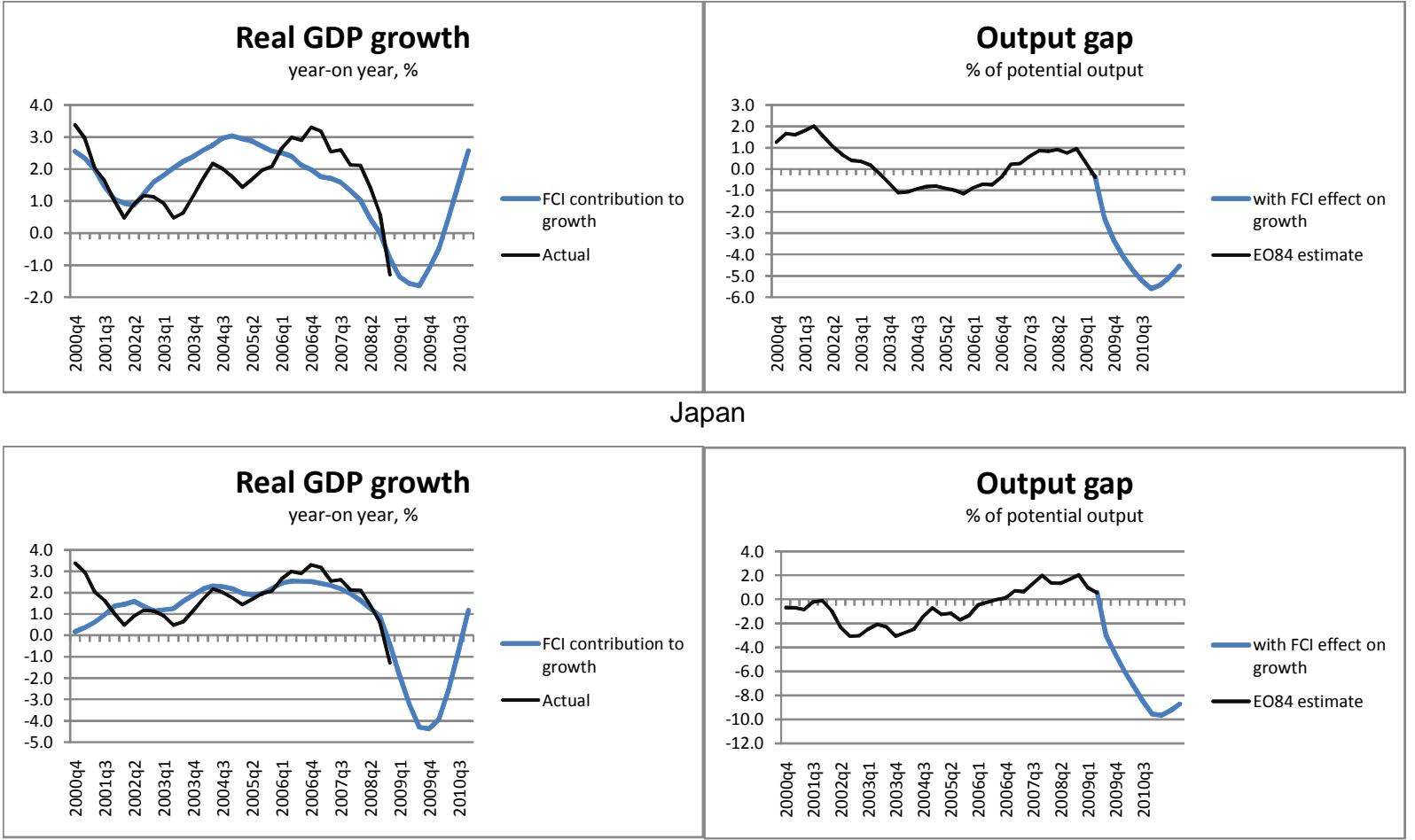

United Kingdom

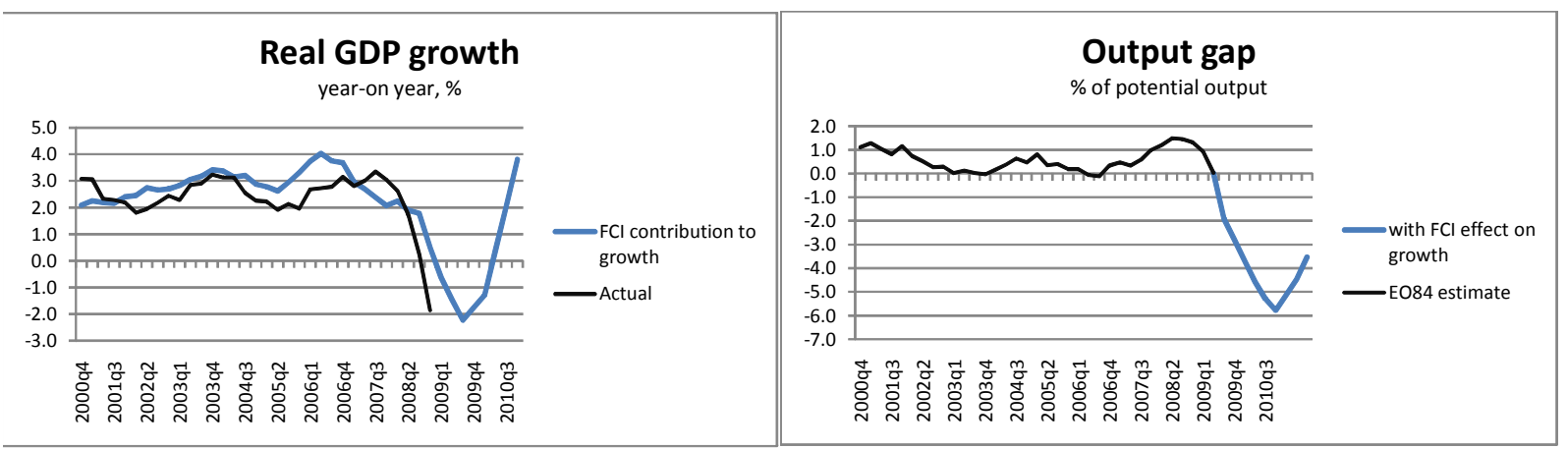

Source: OECD Economic Outlook 84 database; and OECD calculations 


\section{ANNEX 1 \\ TESTING THE SIGNIFICANCE OF CREDIT STANDARDS IN ACCELERATOR-TYPE BUSINESS INVESTMENT EQUATIONS}

The significance of the survey measures of credit standards used in the construction of the FCIs was tested in simple accelerator-type equations for business investment. The effect of a credit standards variable was found to be correctly signed and statistically significant to at least the 5\% level (with the exception of Japan). In all equations the credit standards variable had an economically meaningful impact on business investment, judged by the response to a one standard deviation in credit standards reported in Table A1.1 below. The credit standards variable was consistently found to be more statistically and economically significant than interest rate or other conventional cost of capital variables.

\section{Table A1.1. Testing credit conditions in accelerator equations for business investment}

Dependent variable: $\Delta \mathrm{In}$ IBV

\begin{tabular}{|c|c|c|c|c|}
\hline Estimation period & $\begin{array}{c}\text { United States } \\
\text { 1995Q4-2008Q4 }\end{array}$ & $\begin{array}{c}\text { Euro ar ea } \\
\text { 1999Q4 - 2008Q2 }\end{array}$ & $\begin{array}{c}\text { Japan } \\
\text { 1984Q4 - 2008Q3 }\end{array}$ & $\begin{array}{l}\text { United Kingdom } \\
\text { 1995Q4 - 2008Q4 }\end{array}$ \\
\hline Constant & -0.003 & $-2.442 * *$ & $-1.288 *$ & $-7.580^{* \star *}$ \\
\hline$\Delta \ln$ GDPV & $1.445^{* * *}$ & $1.756 * * *$ & $2.639 * * *$ & $1.885^{* *}$ \\
\hline$\Delta \ln$ GDPV $(-1)$ & $0.892^{* * *}$ & $1.252 * *$ & 0.549 * & \\
\hline$\Delta \ln$ GDPV(-2) & $0.277 *$ & & $1.063 * *$ & \\
\hline In GDPV(-1) & & $0.197 * * *$ & 0.116 * & $0.528 * * *$ \\
\hline$\Delta \ln \operatorname{IBV}(-1)$ & & $-0.222 *$ & $-0.182 *$ & $-0.257^{* *}$ \\
\hline$\Delta \ln I B V(-2)$ & & & & $-0.087 *$ \\
\hline $\ln \operatorname{IBV}(-1)$ & & $-0.123^{* * *}$ & $-0.083^{* * *}$ & $0.275^{* * *}$ \\
\hline$\Delta$ CSTAND(-1) $\times 100$ & $-0.027 *$ & & & \\
\hline $\operatorname{CSTAND}(-3) \times 100$ & & $-0.009 * *$ & $-0.020 *$ & $-0.835^{* \star}$ \\
\hline $\operatorname{CSTAND}(-4) \times 100$ & $-0.045^{* * *}$ & & & \\
\hline Standard Deviation (SD) of CSTAND & 24.1 & 29.2 & 20.05 & 2.16 \\
\hline \multicolumn{5}{|c|}{$\%$ response of IBV to a one SD change in CSTAND: } \\
\hline A verage response after 4-6 quarters & -1.7 & -0.6 & -0.7 & -1.4 \\
\hline Long-run response & - & -2.2 & -4.9 & -2.6 \\
\hline Adjusted R-squared & 0.631 & 0.640 & 0.266 & 0.460 \\
\hline S.E. of regression & 0.011 & 0.206 & 0.538 & 0.229 \\
\hline \multicolumn{5}{|c|}{ 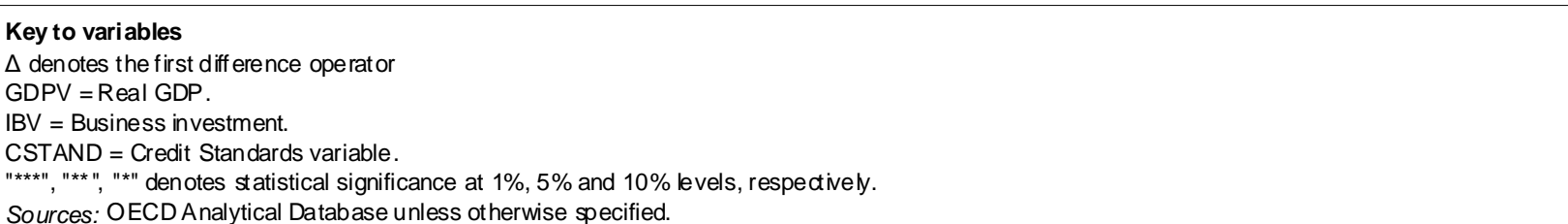 } \\
\hline
\end{tabular}




\section{ANNEX 2 WHY HAS BANK LENDING CONTINUED TO GROW SO RAPIDLY?}

The tightening in credit standards was initially accompanied by an increase in the growth of lending to businesses in the United States and the euro area, although in the second half of 2008 such lending has begun to decelerate sharply. However, a lag between the tightening in standards and subsequent slowing in credit growth is not unusual

Simple regressions relating the growth of bank lending to the non-financial corporate sector to GDP growth and a measure of credit standards are displayed in Table A2.1 for the euro area and the United States. A feature of both equations is that the short-run response to a reported tightening in lending standards is (perversely) increased growth in lending, although in the long run there is, as

\section{Table A2.1Testing the significance of the credit conditions in business investment accelerator equations}

Dependent variable: $\Delta \mathrm{ln}$ IBV

\begin{tabular}{|c|c|c|c|c|}
\hline Estimation period & $\begin{array}{c}\text { United States } \\
\text { 1995Q4 - 2008Q4 }\end{array}$ & $\begin{array}{c}\text { Euro area } \\
\text { 1999Q4 - 2008Q2 }\end{array}$ & $\begin{array}{c}\text { Japan } \\
\text { 1984Q4 - 2008Q3 }\end{array}$ & $\begin{array}{l}\text { United Kingdom } \\
\text { 1995Q4 - 2008Q4 }\end{array}$ \\
\hline Constant & -0.003 & $-2.442^{\star \star}$ & $-1.288^{*}$ & $-7.580^{\star \star \star}$ \\
\hline$\Delta \ln$ GDPV & $1.445^{\star \star *}$ & $1.756^{* * *}$ & $2.639^{* * *}$ & $1.885^{\star *}$ \\
\hline$\Delta \ln \operatorname{GDPV}(-1)$ & $0.892^{\star \star \star}$ & $1.252^{* *}$ & $0.549^{*}$ & \\
\hline$\Delta \ln$ GDPV $(-2)$ & $0.277^{*}$ & & $1.063^{* *}$ & * \\
\hline In GDPV(-1) & & $0.197^{* * *}$ & $0.116^{*}$ & $0.528^{* * *}$ \\
\hline$\Delta \ln$ IBV $(-1)$ & & $-0.222^{*}$ & $-0.182^{*}$ & $-0.257^{* *}$ \\
\hline$\Delta \ln$ IBV $(-2)$ & & & & $-0.087^{\star}$ \\
\hline $\ln \operatorname{IBV}(-1)$ & & $-0.123^{* * *}$ & $-0.083^{* * *}$ & $0.275^{* * *}$ \\
\hline$\Delta \operatorname{CSTAND}(-1) \times 100$ & $-0.027^{*}$ & & & \\
\hline $\operatorname{CSTAND}(-3) \times 100$ & & $-0.009^{* *}$ & $-0.020 *$ & $-0.835^{\star *}$ \\
\hline $\operatorname{CSTAND}(-4) \times 100$ & $-0.045^{\star * *}$ & & & \\
\hline Standard Deviation (SD) of CSTAND & 24.1 & 29.2 & 20.05 & 2.16 \\
\hline \multicolumn{5}{|c|}{$\%$ response of IBV to a one SD change in CSTAND: } \\
\hline Average response after 4-6 quarters & -1.7 & -0.6 & -0.7 & -1.4 \\
\hline Long-run response & - & -2.2 & -4.9 & -2.6 \\
\hline Adjusted R-squared & 0.631 & 0.640 & 0.266 & 0.460 \\
\hline S.E.of regression & 0.011 & 0.206 & 0.538 & 0.229 \\
\hline \multicolumn{5}{|c|}{$\begin{array}{l}\text { Key to variables } \\
\triangle \text { denotes the first difference operator } \\
\text { GDPV }=\text { Real GDP. } \\
\text { IBV }=\text { Business investment. } \\
\text { CSTAND }=\text { Credit Standards variable. } \\
\text { "***", "**", "*" denotes statistical significance at } 1 \%, 5 \% \text { and } 10 \% \text { levels, respectively. } \\
\text { Sources.OECD Analytical Database unless otherwise specified. }\end{array}$} \\
\hline
\end{tabular}


might be expected, a reduction in the growth of bank lending. When the impulse response functions to these equations are evaluated and translated into year-on-year growth rates, there is typically a delay of four or more quarters before a tightening in lending standards is reflected in lower growth in lending (Figure A2.1). Nevertheless, the residuals from these equations suggests that extent of the delayed response from bank lending was unusually long for the current episode.

Figure A2.1 Response of bank lending following a tightening in lending standards

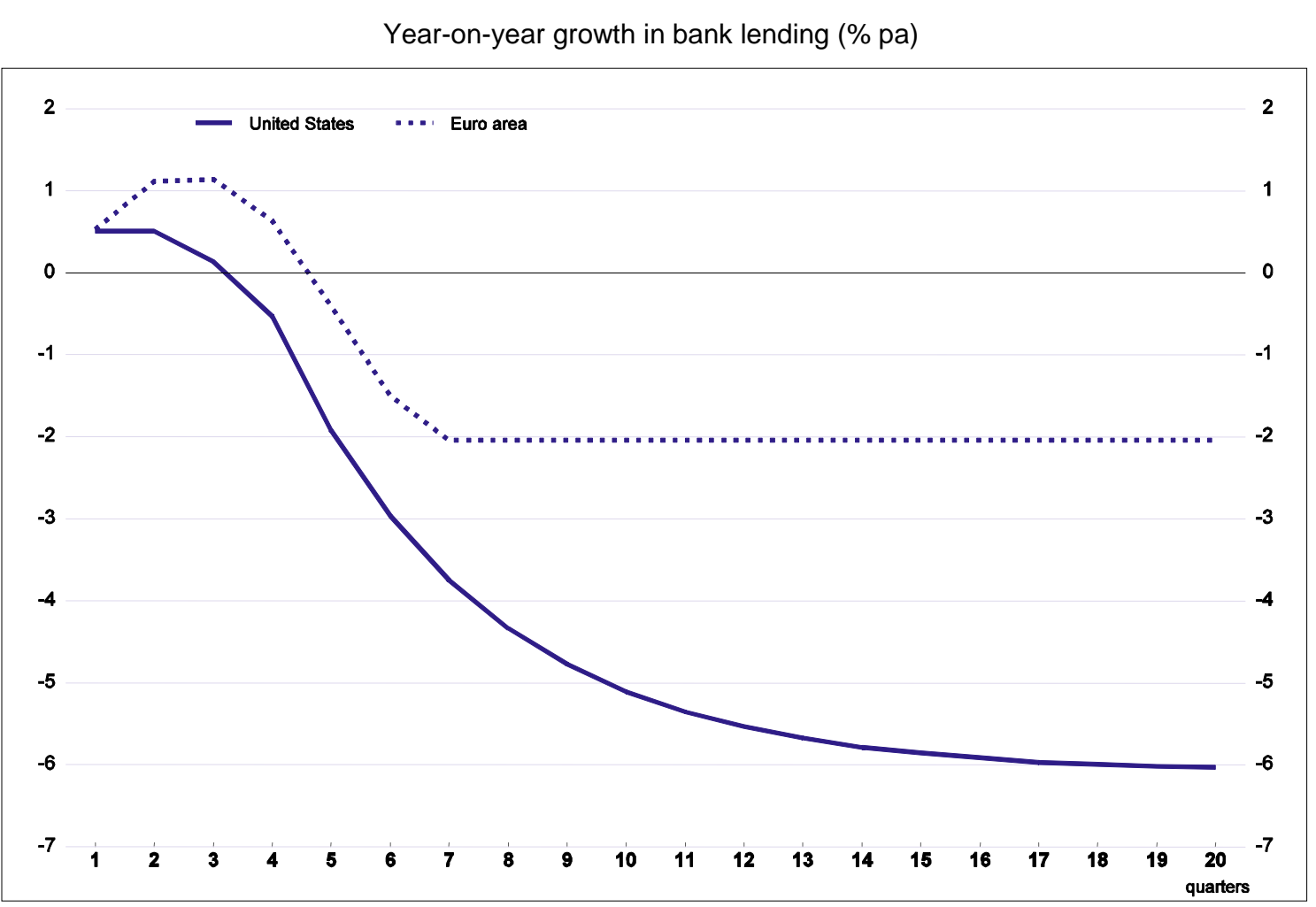

Note: The impulse response functions show the estimated change in the growth rate of bank lending to the non-financial corporate sector following a one standard deviation increase in the number of banks reporting a tightening in lending standards. The estimated equations on which this is based are reported in Annex 2.

\section{Source: OECD calculations.}

Several factors are likely to have contributed to the unusual delay in the response of credit growth to a tightening in lending standards (see Cohen-Cole et al., 2008). First, in the United States, there seems to have been more drawing on past credit lines than during the previous episode of credit tightening in the early 2000s and the drawing on past credit lines has come through faster than in the 1990-92 episode (Figure A2.2). This can be explained by the unusually large reduction in commercial paper issuance, fear of liquidity shortages, and the fact that credit lines were negotiated in much better conditions than current credit standards. Inconsequence, most of the loans originated in the past two years had loose covenants, which do not prevent companies from drawing on their credit lines even if their financial conditions worsen. Moreover, loan securitisation has become more difficult, resulting in an increase in the loans reported on banks' balance sheets, which has masked the fact that new loans are contracting. In particular, Ivashina and Scharfstein (2008) using Reuters' DealScan database of large bank loans show that new lending contracted in 2008 and that this decline accelerated when the financial crisis intensified in the autumn of 2008. The amount of new loans to large borrowers during the peak period of the financial crisis (August-October 2008) was 60\% lower than during the peak of the credit boom (May-July 2007). The 
contraction was steepest for below-investment grade borrowers. New lending for real investment (such as capital expenditures) and for restructuring (LBOs, M\&A, share repurchases) were affected equally.

\section{Figure A2.2 The realisation of credit lines and credit standards}

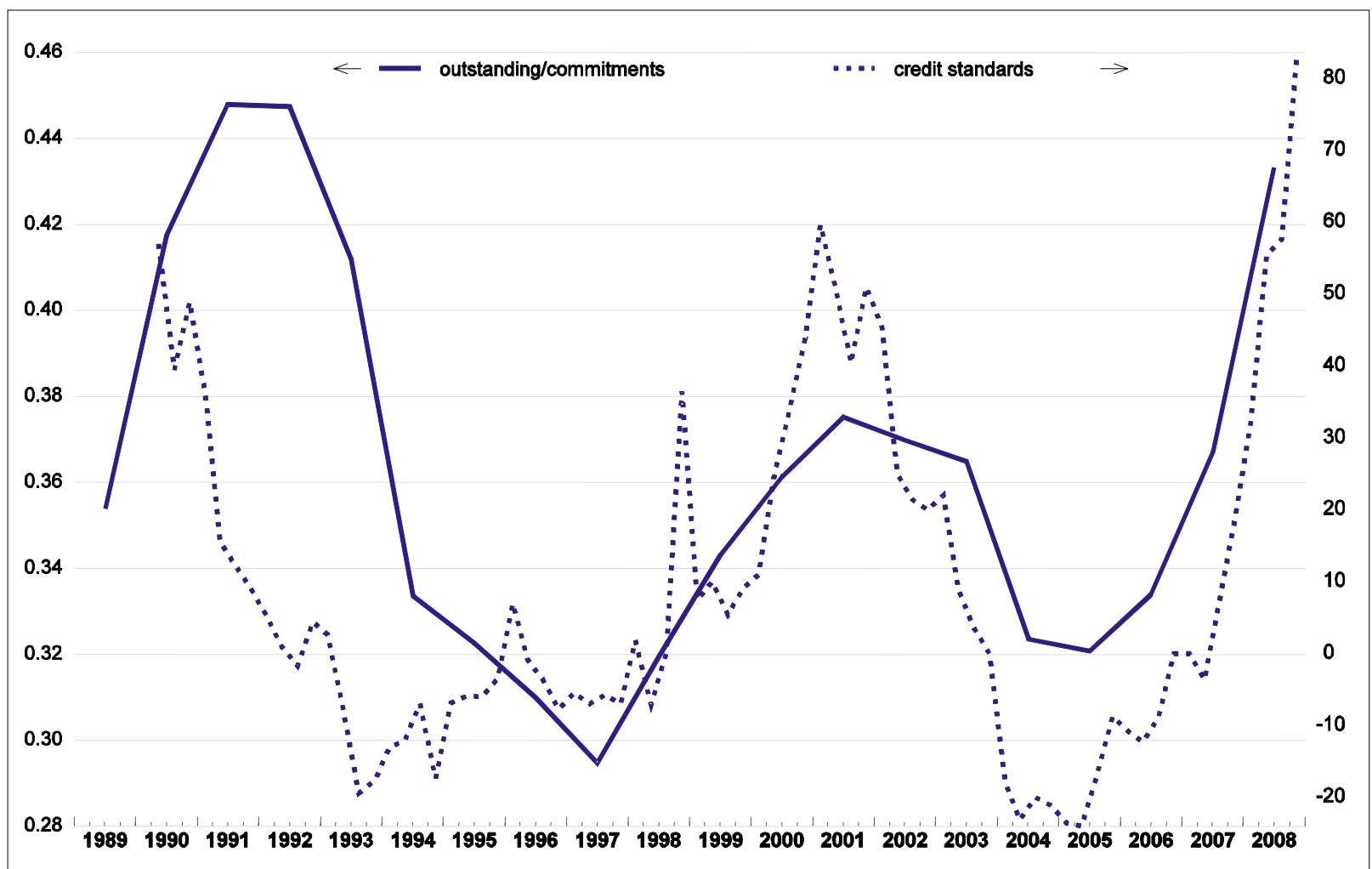

Note: The outstanding/commitment ratio is the proportion of outstanding credit lines which are realised relative to the total of committed outstanding credit lines. The data is taken from the Shared National Credits Program Report. Credit standards are measured according to the Senior Loan Officer Opinion Survey, a higher figure represents a tightening.

Source: US Federal Reserve, OECD calculations. 


\section{BIBLIOGRAPHY}

Altissimo, F. et al. (2005), "Wealth and Asset Price Effects on Economic Activity", European Central Bank Occasional Paper Series, No. 29, June.

Angeloni, I., A. Kashyap, and B. Mojon (2003a), Monetary Policy Transmission in the Euro Area, Cambridge University Press.

Angeloni, I., A. Kashyap, B. Mojon and D. Terlizzese (2003b), "Monetary Policy Transmission in the Euro Area: Where do we Stand ?", Chapter in Angeloni et al. (2003a).

Bê Duc, L., G. de Bondt, A. Calza, D. Marqués Ibáñez, A. Van Rixtel and S. Scopel (2005) "“Financing Conditions in the Euro Area", ECB Occasional Paper, No. 37.

Bernanke, B. and M. Gertler (1989), “Agency Costs, Net Worth, and Business Fluctuations”, American Economic Review, No. 79.

Catte, P., N. Girouard, R. Price and C. André, 2004. "Housing Markets, Wealth and the Business Cycle", OECD Economics Department Working Papers, No. 394.

Chan-Lau, J. and I. Ivaschenko (2001), "Corporate Bond Risk and Real Activity: An Empirical Analysis of Yield Spreads and their Systematic Components”, IMF Working Paper, No. 01/158.

Cohen-Cole, E., B. Duygan-Bump, J. Fillat, and J. Montoriol-Garriga (2008), "Looking Behind the Aggregates: A Reply to "Facts and Myths about the Financial Crisis of 2008", QAU Working Paper, No. QAU08-5.

Cournède, B., R. Ahrend and R. Price (2008), "Have Long-Term Financial Trends Changed the Transmission of Monetary Policy", OECD Economics Department Working Papers, No. 634.

Dalsgaard, T, C. André and P. Richardson (2001), "Standard Shocks in the OECD Interlink Model", OECD Economic Department Working Papers, No. 306.

De Bondt, G. (2002), Euro Area Corporate Debt Securities Market: First Empirical Evidence”, ECB Working Paper, No. 164.

Feldstein, M. (1997), “The Costs and Benefits of Going from Low Inflation to Price Stability”, in Romer, C. and D. Romer (ed.), Reducing Inflation, University of Chicago Press.

Friedman, M. (1957), A Theory of the Consumption Function, Princeton University Press.

Gertler, M, and C. Lown (2000), "The Information in the High Yield Bond Spread for the Business Cycle: Evidence and Some Implications", NBER Working Paper, No. 7549.

Guichard, S., and D. Turner (2008), "Quantifying the Effect of Financial Conditions on US Activity", OECD Economics Department Working Papers, No. 635, September. 
Hervé, K. et al. (2009), “The OECD’s New Global Model”, OECD Economics Department Working Papers, forthcoming.

Ivashina, V.and D. Scharfstein (2008). "Bank Lending During the Financial Crisis of 2008", available from: http://www.people.hbs.edu/dscharfstein/Lending_During the_Crisis.pdf.

Labhard, V., G. Sterne and C. Young (2005), "Wealth and Consumption: An Assessment of the International Evidence", Bank of England Working Paper, No. 275, October.

Lown, C. and D. Morgan (2004), "The Credit Cycle and the Business Cycle: New Findings Using the Loan Officer Opinion Survey", research report from Stockholm institute for financial research, No. 27, September.

Muellbauer, J., (2007), "Housing, Credit and Consumer Expenditure”, by John, FRB/Kansas City Symposium on Housing, Housing Finance and Monetary Policy, Jackson Hole, WY, 31 August to 1 September.

Mody, A., and M. Taylor (2003), "The High-Yield Spread as a Predictor of Real Economic Activity: Evidence of a Financial Accelerator for the United States", IMF Staff Papers, Vol. 50, No. 3.

Motonishi, T. and H. Yoshikawa (1999), "Causes of the Long Stagnation of Japan during the 1990s: Financial or Real?", Journal of the Japanese and International Economies, Vol. 13.

Muellbauer, J. (2008), “A Housing-led Recession in the Making: Housing Wealth and Consumer Spending", online mimeo at VoxEU.org, July.

Nelson, E. and A. Schwarz (2008), "The Impact of Milton Friedman on Modern Monetary Economics: Setting the Record Straight on Paul Krugman's 'Who Was Milton Friedman?'”, Journal of Monetary Economics, Vol. 55, No. 4.

OECD (2008a), Economic Survey of United States, Paris.

OECD (2008b), OECD Economic Outlook, No. 84, November, Paris.

OECD (2009), Economic Survey of Euro Area, forthcoming, Paris.

Peersman, G. and F. Smets (2003), "The Monetary Transmission Mechanism in the Euro Area: Evidence from VAR Analysis," Chapter in Angeloni et al. (2003a).

Poterba, J.M. (2000), “Stock Market Wealth and Consumption”, Journal of Economic Perspectives, No. 14.

Rudebusch, G.D. and J.C. Williams (2008), "Revealing the Secrets of the Temple: the Value of Publishing Central Bank Interest Rate Projections", in: J.Y. Campbell (ed.), Asset Prices and Monetary Policy, National Bureau of Economic Research.

Svensson, L.E.O. (2008), “Transparency under Flexible Inflation Targeting: Experiences and Challenges", Conference on Refining Monetary Policy: Transparency and Real Stability, Riksbank.

Swiston, A. (2008), “A US Financial Conditions Index: Putting Credit Where Credit is Due”, IMF Working paper, No. 08/161. 
Thornton, D. (2006), "Measured Pace in the Conduct of Monetary Policy", Monetary Trends, Federal Reserve Bank of Saint Louis, March.

Tobin, J. (1969), “A General Equilibrium Approach to Monetary Theory”, Journal of Money, Credit and Banking, No. 1.

Ugai, H. (2007), "Effects of the Quantitative Easing Policy: A Survey of Empirical Analyses", Bank of Japan Monetary and Economic Studies, Vol. 25.

UK Treasury (2003), EMU Study: EMU and Monetary Transmission Mechanism, http:www.hm-treasury.gov.uk.

Woodford, M. (2008), “The Fed's 'Enhanced' Communication Strategy: Work in Progress”, remarks prepared for the NABE session, January. 


\section{WORKING PAPERS}

The full series of Economics Department Working Papers can be consulted at www.oecd.org/eco/Working_Papers/

676. Taking Stock of Existing Structural Policy and Outcome Indicators (month 2009) Davide Furceri and Annabelle Mourougane

675. Stabilization Effects of Social Spending: Empirical Evidence from a Panel of OECD Countries (February 2009) Davide Furceri

674. Fiscal Convergence, Business Cycle Volatility and Growth (February 2009) Davide Furceri

673. Boosting Productivity in Korea's service sector (February 2009) Randall S. Jones

672. Sustaining growth in Korea by reforming the labour market and improving the education system (February 2009) Randall S. Jones and Masahiko Tsutsumi

671. Reforming the tax system to promote economic growth and cope with rapid population ageing (February 2009) Randall S. Jones

670. Financial market stability: Enhancing regulation and supervision (February 2009) Jeremy Lawson, Sebastian Barnes and Marte Sollie

669. Overcoming the financial crisis (February 2009) Andrea De Michelis

668. Financial crises: past lessons and policy implications (February 2009) Davide Furceri and Annabelle Mourougane

667. Reforms to open sheltered sectors to competition in Switzerland (February 2009) Andrés Fuentes

666. Raising education outcomes in Spain (February 2009) Andrés Fuentes

665. Health care reform in the United States (February 2009) David Carey, Bradley Herring and Patrick Lenain

664. The role of $R \& D$ and technology diffusion in climate change mitigation: new perspectives using the WITCH model (February 2009) Valentina Bosetti, Carlo Carraro, Romain Duval, Alessandra Sgobbi and Massimo Tavoni

663. Long-run GDP growth framework and scenarios for the world economy (January 2009) Romain Duval and Christine de la Maisonneuve 
662. Realising South Africa's employment potential (January 2009) Geoff Barnard

661. Making the most of Norwegian schools (January 2009) Romina Boarini

660 Can the financial sector continue to be the main growth engine in Luxembourg? (January 2009) Arnaud Bourgain, Patrice Pieretti and Jens Høj

659. Fiscal policy responsiveness, persistence, and discretion (December 2008) António Afonso, Luca Agnello, Davide Furceri

658. The economics of climate change mitigation: policies and options for the future (December 2008) Jean-Marc Burniaux, Jean Chateau, Romain Duval and Stéphanie Jamet

657. Maximising Mexico's gains from integration in the world economy (December 2008) David Haugh, Roselyne Jamin and Bruno Rocha

656. How do taxes affect investment and productivity? An industry-level analysis of OECD countries (December 2008) Laura Vartia

655. Strategies for countries with favourable fiscal positions

(November 2008) Robert Price, Isabelle Joumard, Christophe André and Makoto Minegishi

654. Monetary transmission mechanism in Central and Eastern Europe: Surveying the Surveable (November 2008) Balázs Égert and Ronald MacDonald

653. An Overview of the OECD ENV-Linkages Model Jean-Marc Burniaux and Jean Château

652. Reforming the labour market in Japan to cope with increasing dualism and population ageing (November 2008) Randall S. Jones

651. Enhancing the productivity of the service sector in Japan (November 2008) Randall S. Jones and Taesik Yoon

650. Reforming the tax system in Japan to promote fiscal sustainability and economic growth (November 2008) Randall S. Jones and Masahiko Tsutsumi

649. What Drives the NAIRU? Evidence from a Panel of OECD Countries (November 2008) Christian Gianella, Isabell Koske, Elena Rusticelli and Olivier Chatal

648. Short-term distributional effects of structural reforms: selected simulations in a DGSE framework (October 2008) Annabelle Mourougane and Lukas Vogel

647. Speed of adjustment to selected labour market and tax reforms (October 2008) Annabelle Mourougane, Lukas Vogel

646. The challenge of monetary policy in Turkey (October 2008) Olcay Çulha, Ali Çulha and Rauf Gönenç 